California State University, Monterey Bay

Digital Commons@ @ CSUMB

$11-2004$

New Paleomagnetic, Rock Magnetic, and Petrographic Results

from the Valle Group, Baja California, Mexico: Exploring the Causes of Anomalously Shallow Paleomagnetic Inclinations

Yong-Xiang Li

Kenneth P. Kodama

Douglas P. Smith

Follow this and additional works at: https://digitalcommons.csumb.edu/sns_fac

This Article is brought to you for free and open access by the School of Natural Sciences at Digital Commons @ CSUMB. It has been accepted for inclusion in School of Natural Sciences Faculty Publications and Presentations by an authorized administrator of Digital Commons @ CSUMB. For more information, please contact digitalcommons@csumb.edu. 


\title{
New paleomagnetic, rock magnetic, and petrographic results from the Valle Group, Baja California, Mexico: Exploring the causes of anomalously shallow paleomagnetic inclinations
}

\author{
Yong-Xiang Li and Kenneth P. Kodama \\ Department of Earth and Environmental Science, Lehigh University, Bethlehem, Pennsylvania, USA \\ Douglas P. Smith \\ Division of Science and Environmental Policy, California State University, Monterey Bay, Seaside, California, USA \\ Received 5 April 2004; revised 4 August 2004; accepted 25 August 2004; published 13 November 2004.
}

[1] A detailed paleomagnetic, rock magnetic, and sedimentologic study was conducted on Cenomanian-age strata of the Valle Group at El Campito, Baja California, to examine the burial compaction effects on the paleomagnetic inclination of marine sedimentary rocks. Alternating field and thermal demagnetization isolated a characteristic remanence at 16 of 18 sites with a mean of Dec $=342.6^{\circ}$, Inc $=19.1^{\circ}$, and $\alpha_{95}=3.4^{\circ}$. The inclination is $38.7^{\circ}$ shallower than that predicted by the reference paleopole for North America. Laboratory experiments indicate that compaction could account for only $7.5^{\circ}$ of the inclination shallowing. Fold tests at different scales yield both positive and negative results, making a tight constraint on the remanence's age impossible. A primary postdepositional remanence is supported by bedding-parallel foliations in the anisotropy of anhysteretic remanence fabric. Although primary anomalously shallow inclinations could indicate significant southerly, then northerly, paleolatitudinal offset, a more likely scenario is a late Cenozoic low-temperature remagnetization, which is suggested by alteration along the edges of some detrital silicate grains and a bimodal magnetic grain size distribution revealed by isothermal remanence data. The synthesis of the data indicates that the Vizcaino terrane was contiguous with the Cordillera margin during remagnetization and underwent a subsequent $13.5 \pm 5.4^{\circ}$ clockwise rotation. We tentatively interpret that the remagnetization resulted from burial and/or Miocene volcanism, which caused an acquisition of thermochemical remanent magnetization (TCRM). This study reveals a complicated remanence that resists easy interpretation and suggests caution in studies of similar rocks. INDEX TERMS: 1525 Geomagnetism and Paleomagnetism: Paleomagnetism applied to tectonics (regional, global); 1527 Geomagnetism and Paleomagnetism: Paleomagnetism applied to geologic processes; 1533 Geomagnetism and Paleomagnetism: Remagnetization; 1540 Geomagnetism and Paleomagnetism: Rock and mineral magnetism; KEYWORDS: paleomagnetism, shallow inclination, Valle, Baja California, remagnetization, Cretaceous

Citation: Li, Y.-X., K. P. Kodama, and D. P. Smith (2004), New paleomagnetic, rock magnetic, and petrographic results from the Valle Group, Baja California, Mexico: Exploring the causes of anomalously shallow paleomagnetic inclinations, J. Geophys. Res., 109, B11101, doi:10.1029/2004JB003127.

\section{Introduction}

[2] The paleogeographic reconstruction of the North American Cordillera since the late Mesozoic has been controversial for many years [Beck, 1991; Butler et al., 1989, 1991; Irving et al., 1995; Cowan et al., 1997; Dickinson and Butler, 1998; Housen and Beck, 1999]. Central to this controversy is the timing and magnitude of terrane displacement suggested by the apparently conflicting paleomagnetic and geologic data [e.g., Gastil, 1991; Beck, 1991]. In Baja California, the paleomagnetic

Copyright 2004 by the American Geophysical Union. 0148-0227/04/2004JB003127\$09.00 inclinations of the Cretaceous-early Tertiary rocks are shallower than coeval inclinations from North America. The shallow inclinations have been interpreted to indicate over $\sim 1000 \mathrm{~km}$ of northward terrane displacement of Baja California along the North American craton since the Cretaceous [Teissere and Beck, 1973; Patterson, 1984; Fry et al., 1985; Hagstrum et al., 1985; Morris et al., 1986; Beck, 1991; Smith and Busby, 1993a; Hagstrum and Sedlock, 1998].

[3] In contrast, key lithologic units such as Paleozoic rocks and a belt of high-grade metamorphic rocks in Baja California can be correlated with similar features in mainland Mexico [Gastil, 1991], indicating that the offset is limited. The interpretation of limited terrane displacement is 
strengthened by the presence of similar detrital zircon ages in the lower Paleozoic quartzites of northeastern Baja and the lower Paleozoic units in the Cordilleran margin [Gehrels et al., 2002]. Further support is provided by the paleopole derived from the Cretaceous San Telmo pluton in northern Baja California, which is concordant with the North American reference pole [Böhnel and Delgado-Argote, 2000]. These studies argue for very limited amounts of displacement that could be explained by the opening of the California Gulf in the late Tertiary and the subsequent evolution of San Andreas Fault system without invoking long-distance travel of terranes.

[4] The accuracy of paleomagnetic records in rocks is crucial for solving the controversy of terrane transport history in Baja California. Critical evaluation of paleomagnetic records has led to three alternative interpretations of anomalously shallow paleomagnetic inclinations that do not require long-distance displacement. These interpretations include remagnetization, postemplacement tilt of igneous rocks, and burial compaction of sedimentary rocks.

[5] A posttilting remagnetization could cause anomalously shallow paleomagnetic inclinations in stratigraphic coordinates. At least two episodes of remagnetization during Late Cretaceous and Tertiary time have been recognized from a number of formations in Baja California [Hagstrum et al., 1985; Kamerling and Luyendyk, 1985; Hagstrum and Filmer, 1990; Hagstrum and Murchey, 1993] and these remagnetization events were probably widespread in Baja California [Hagstrum and Sedlock, 1998].

[6] Postemplacement tilt of the Cretaceous and early Tertiary plutonic rocks has been considered as an alternative explanation for their shallow inclinations. A regional tilt about a NW trending axis would uplift the northeast side of the igneous bodies and result in shallow inclinations [Butler et al., 1991]. Although a paleobarometric study of the Peninsular Ranges batholith argued that the regional tilt can explain only a small amount of the anomalously shallow inclinations [Ague and Brandon, 1992], the difference in the amounts of tilting indicated by paleomagnetic data and paleobarometric data could result from the combined uncertainties in the two data sets [Dickinson and Butler, 1998]. The possibility of postemplacement tilt of the batholith has gained support from later studies. A thermochronologic study of the plutons in northern Baja California [Ortega-Rivera et al., 1997] showed an eastward decrease of ${ }^{40} \mathrm{Ar} /{ }^{39} \mathrm{Ar}$ and apatite fission track ages that was interpreted to indicate $\sim 15^{\circ}$ of east-side-up tilting of the batholith about an axis subparallel to the trend of the Peninsular Ranges batholith. This tilting could account for the batholith's anomalously shallow inclination without requiring large-scale northward displacement. In a recent paleomagnetic study of middle Cretaceous intrusive rocks from northern Baja California, Böhnel et al. [2002] showed that batholith tilting can explain not only shallow inclinations, but also the declination anomaly that would otherwise require a clockwise vertical axis rotation, which the local geologic data do not support.

[7] Burial compaction is believed to be an alternative interpretation for shallow inclinations observed in sedimentary rocks [Butler et al., 1991; Dickinson and Butler, 1998; Butler et al., 2001]. Postdepositional compaction would rotate remanence-carrying detrital grains toward the hori- zontal, thus causing shallow inclinations. Laboratory compaction studies of Cretaceous turbidites from southern California have demonstrated that most or all of the anomalously shallow inclinations of the Cretaceous marine sediments from the Peninsular Ranges terrane could be explained by burial compaction without invoking very large-scale latitudinal translation [Kodama and Davi, 1995; Tan and Kodama, 1998; Kodama and Ward, 2001].

[8] Although burial compaction has been demonstrated to be a promising solution for the terrane displacement controversy in southern California, the compaction effect on the majority of marine sediments in Baja California remains unstudied. It is therefore necessary to extend the compaction correction work to include the sedimentary units in Baja California to examine whether or not, and to what extent, burial compaction may bias their paleomagnetic records. As part of our continuing program of studying the sedimentologic controls on paleomagnetic records in sedimentary rocks, we carried out a paleomagnetic, rock magnetic, and sedimentologic study on a well-exposed coastal outcrop of middle Cretaceous forearc strata (Valle Group) on the Vizcaino Peninsula, Baja California, Mexico. Our initial goal in this study was to estimate and correct the inclination error caused by burial compaction.

\section{Regional Geological Setting}

[9] The Vizcaino Peninsula and Cedros Island are located in western central Baja California (Figure 1). The remnants of an upper Triassic opholite, which was disrupted by Jurassic-early Cretaceous volcanic and plutonic rocks, form the basement of this region. Overlying the paleooceanic basement rocks are Cretaceous-Paleogene marine sediments [Kimbrough, 1985; Moore, 1985; Abbott et al., 1995]. The rock units on the Vizcaino Peninsula cannot be easily correlated with stratigraphic units further to the east in terms of age, petrologic characteristics, and facies, leaving the possibility that the Vizcaino peninsula is a separate terrane. It has been designated the Vizcaino terrane [Coney et al., 1980]. The Vizcaino terrane lies to the west of the Santa Ana terrane of Baja California, separated by a fault that is inferred to lie buried beneath upper Cenozoic deposits [Butler et al., 1991; Sedlock et al., 1993] (Figure 1). The Vizcaino Terrane probably originated in a marginal basin receiving deposits from island arcs during the TriassicJurassic that fringed cratonic North America [Rangin, 1978; Gastil et al., 1978]. The subsequent evolution of this region involved extension in the fringing arcs, compression in the continental arc, and later translation along the western North American margin [Smith and Busby, 1993b; Busby et $a l ., 1998]$. The exact timing of the Vizcaino Terrane accretion onto marginal North America, however, is not well constrained, ranging from middle Jurassic to late Early Cretaceous time [Boles and Landis, 1984; Kimbrough, 1985; Moore, 1985].

[10] The Cretaceous Valle Group crops out extensively on the Vizcaino Peninsula and Cedros Island and consists of terrigenous sandstones, shales, and conglomerates that accumulated as sediment gravity flow (SGF) deposits in a forearc basin [Morris et al., 1989; Smith et al., 1993]. The Valle Group uncomformably overlies middle Mesozoic island arc rocks [Kimbrough, 1985; Smith et al., 


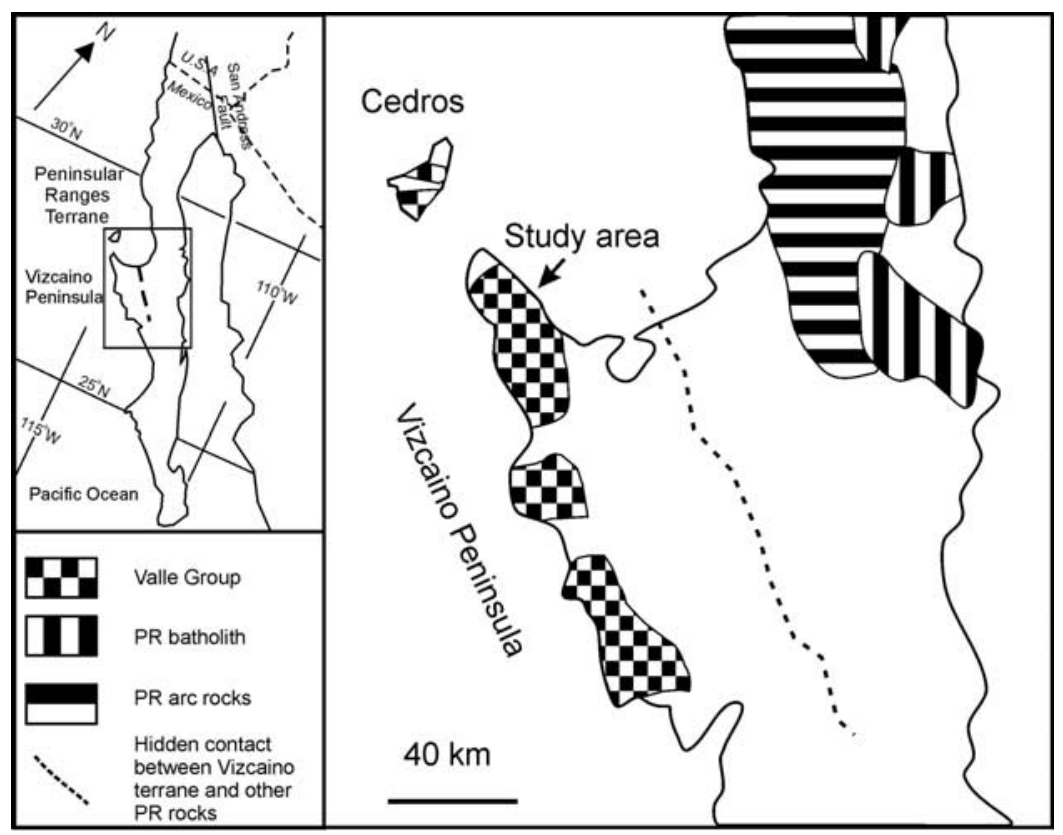

Figure 1. Simplified geological map of the Valle Group on the Vizcaino Peninsula and Cedros Island, Baja California, Mexico. The El Campito section (study area) is located at the northern coast of the peninsula and consists of middle Cenomanian sedimentary rocks.

1993] and is uncomformably overlain by Miocene and Pliocene strata that tie the Vizcaino terrane to the Baja California Peninsula and the Santa Ana Terrane. The Valle sediments were probably derived from the Peninsular Ranges batholith along the continental margin [Kimbrough et al., 2001]. Detailed sedimentologic studies show that the Valle Group exposed on Cedros Island was deposited in an extensional, fault-controlled basin, analogous to modern forearc basins experiencing shear in the Aleutian and Indonesian convergent margins [Smith and Busby, 1993b; Busby et al., 1998].

[11] Rocks in western central Baja California generally yield shallow paleomagnetic inclinations that are often interpreted to indicate over $1000 \mathrm{~km}$ northward displacement with respect to the cratonic North America since the Late Cretaceous [Patterson, 1984; Hagstrum et al., 1985; Smith and Busby, 1993a]. Paleomagnetic studies of the Mesozoic red radiolarian cherts from Cedros Island and the San Benito Islands, and pillow basalts from Vizcaino peninsula suggest that the paleooceanic basement rocks appear to have experienced remagnetiztion in the middle Cretaceous [Hagstrum and Sedlock, 1990, 1992; Hagstrum et al., 1993]. Some of the Cretaceous sedimentary rocks in the Vizcanio peninsula may also have been magnetically overprinted [Hagstrum et al., 1985]. Since many rocks of the Coast Range Ophiolite, Great Valley Sequence, Fransican Complex in California, and some Cretaceous rocks in southern Baja California are shown to be remagnetized as well [Hagstrum, 1992; Hagstrum and Murchey, 1993, 1996; Hagstrum and Sedlock, 1998], remagnetization probably occurred extensively along the California margin [Hagstrum and Sedlock, 1998]. Despite the apparently widespread remagnetization, the northern exposures of the Valle Group forearc basin appear to carry a primary remanence [Smith and Busby, 1993a]. Remanence of the Valle rocks from
Cedros Island has positive fold tests and has been interpreted indicating $20^{\circ} \pm 10^{\circ}$ polarward displacement and clockwise rotation [Smith and Busby, 1993a]. The Valle rocks in El Campito, on the northern coast of the Vizcaino peninsula, were initially shown to carry a primary remanence [Hagstrum et al., 1985], and were later thought to be remagnetized [Hagstrum and Sedlock, 1998]. However, only 2 sites (12 samples) from El Campito were analyzed in the earlier study [Hagstrum et al., 1985] and are inadequate for a separate fold test. Therefore the age of the remanence of the El Campito Valle rocks is yet to be determined. The burial compaction effect on the inclination of the Valle rocks was first examined in Smith and Busby's [1993a] paleomagnetic study. The lack of a correlation between inclination and grain size led the authors to conclude that compaction did not affect the paleomagnetic inclinations in these sedimentary rocks. However, this interpretation probably oversimplified the magnetization acquisition processes [Butler and Dickinson, 1995]. Sedimentary facies and clay content of rocks apparently affect the magnitude of the compaction effect on paleomagnetic inclinations [Dickinson and Butler, 1998; Tan and Kodama, 1998]. Clearly, the differing views on the shallow inclinations of sedimentary rocks require additional paleomagnetic work to shed light on the role of remagnetization and compaction in causing the shallow inclinations observed in the Vizcaino terrane.

\section{Methods}

\subsection{Paleomagnetic Study}

[12] We collected 18 sites from the middle Cretaceous Valle Group at El Campito, northeastern Vizcaino Peninsula, with a gasoline-powered portable rock drill. Six to ten $25 \mathrm{~mm}$ diameter cores were drilled from each site and 
the individual cores were oriented with a Brunton compass mounted on an aluminum orientation table. Cores were then taken to the laboratory and trimmed to $22 \mathrm{~mm}$ long standard paleomagnetic specimens with a dual-bladed rock saw. Each site typically has $\sim 10$ cylindrical specimens for laboratory measurements except Sites 10A, 10B, and 10C where more samples were collected from graded beds to examine whether sediment grain size would affect any burial compaction shallowing of inclinations. The sampled section is about $200 \mathrm{~m}$ thick and is middle Cenomonian ( $\sim 90-95 \mathrm{Ma})$ in age [Berry and Miller, 1984]. The lithology of strata sampled includes coarse to fine-grained sandstone, siltstone, and very fine-grained siltstone. The El Campito section of the Valle Group probably represents channelized, high-energy flow deposits accumulated as turbidites on a submarine fan, or near the mouth of a submarine canyon (D. P. Smith, unpublished data, 1996). The strata of the El Campito section show generally consistent attitudes, striking approximately $300^{\circ}$ and dipping about $55^{\circ}$ to the northeast.

[13] All samples were demagnetized using either alternating field (af) or thermal methods. In order to evaluate the demagnetization behavior of the individual rock unit, half the specimens from each site were subjected to stepwise af demagnetization and the remaining half were treated with progressive thermal demagnetization. The progressive stepwise demagnetization was conducted in 5 or $10 \mathrm{mT}$ increments up to $130 \mathrm{mT}$ for af demagnetization and in $50^{\circ} \mathrm{C}$ steps up to $610^{\circ} \mathrm{C}$ for thermal demagnetization. The af demagnetization and all remanence measurements were made with a $2 \mathrm{G}$ Enterprises Inc. cryogenic magnetometer. Thermal demagnetization was conducted with a Schonstedt TSD-1. Principal component analysis [Kirschvink, 1980] was conducted to isolate the characteristic remanent magnetization (ChRM) and Fisher statistics [Fisher, 1953] were utilized to calculate site mean directions. DirectionCorrection (DC) tilt tests [Enkin, 2003] and inclination-only fold tests [Watson and Enkin, 1993; Enkin and Watson, 1996] were performed to estimate the timing of remanence acquisition. The demagnetization data are presented graphically with vector end point plots [Zijderveld, 1967]. Paleomagnetic software packages PMGSC (by Randolph Enkin), IAPD and GMAP (by Trond Torsvik), and IRM-CLG1.0 (by Pauline Kruiver) were used to perform data analyses and produce some figures.

\subsection{Rock Magnetic Study}

\subsubsection{Rock Magnetic Measurements}

[14] Rock magnetic investigations were carried out to characterize the magnetic fabrics, magnetic mineralogy, and grain size of magnetic minerals. The anisotropy of magnetic susceptibility (AMS) of all specimens was measured with a KLY-3S Kappabridge to determine the magnetic fabrics. Partial anhysteretic remanent magnetization (pARM) was measured for 16 representative samples to determine the magnetic coercivity spectra of the samples. In the pARM experiment, a sample was magnetized in $10 \mathrm{mT}$ af windows from $0 \mathrm{mT}$ to $100 \mathrm{mT}$, in the presence of an $0.1 \mathrm{mT}$ DC magnetic field. The pARM coercivity spectra and the af demagnetization fields used to isolate the ChRMs were utilized to determine the coercivity windows of applied fields for the anisotropy of anhysteretic remanence
(AAR) experiments. An AAR was applied to 33 af demagnetized specimens with a $30-100 \mathrm{mT}$ window in the presence of $0.1 \mathrm{mT}$ DC magnetic field. The AAR of a sample was determined using McCabe et al.'s [1985] approach in which the sample acquired pARMs along nine different orientations. Between each position of pARM acquisition, the sample was measured and then demagnetized at $150 \mathrm{mT}$. The AAR data were used in conjunction with data from laboratory compaction experiments for an inclination correction.

[15] Isothermal remanent magnetization (IRM) acquisition experiments were conducted with an ASC pulse magnetizer on 18 specimens, one from each site, to aid in magnetic mineralogy determination. In each isothermal remanent magnetization (IRM) acquisition experiment, a forward field was applied that gradually increased from $20 \mathrm{mT}$ to $1000 \mathrm{mT}$ in 11 incremental steps. Six representative samples were subjected to detailed IRM acquisition in a forward field increasing from $5 \mathrm{mT}$ to $1000 \mathrm{mT}$ in 30 steps in order to identify the dominant coercivity components in the samples [Kruiver et al., 2001]. A Lowrie test was performed on four representative specimens to further delineate the magnetic mineralogy [Lowrie, 1990]. The samples were magnetized in sequence along their $Z, Y$, and $X$ axes with fields of $1.0 \mathrm{~T}, 0.3 \mathrm{~T}$, and $0.1 \mathrm{~T}$, respectively. The composite IRM was then thermally demagnetized up to $675^{\circ} \mathrm{C}$.

[16] High-temperature, low-temperature, and hysteresis loop measurements of representative samples were carried out at the Institute for Rock Magnetism (IRM) in University of Minnesota. High-temperature susceptibility was measured using a Geofyzika Kappabridge. The high-temperature dipole moments were measured on a Micro Vibrating Sample Magnetometer (MicroVSM) during a heating-cooling cycle with an applied field of $200 \mathrm{mT}$ or $300 \mathrm{mT}$ depending upon the saturation magnetization of the ferrimagnetic fractions. Low-temperature measurements were performed on a Magnetic Property Measurement System (MPMS). The samples first acquired a saturation isothermal remanent magnetization (SIRM) in a $2.5 \mathrm{~T}$ field at $20 \mathrm{~K}$ prior to heating to room temperature. After the temperature was increased to $300 \mathrm{~K}$, the samples were magnetized in a $2.5 \mathrm{~T}$ field again, and then cooled to $20 \mathrm{~K}$. The magnetic moments were measured during both the thermal decay of the $20 \mathrm{~K}$ SIRM and the cooling of the $300 \mathrm{~K}$ SIRM. Measurement of hysteresis loops was conducted on a Vibrating Sample Magnetometer [Princeton Measurements] with a maximum applied field of $1.0 \mathrm{~T}$. The hysteresis parameters include saturation remanent magnetization (Mrs), saturation magnetization (Ms), coercive force (Hc), high-field susceptibility, and remanence coercivity (Hcr). The measured hysteresis parameters were analyzed with Day plot [Day et al., 1977] to characterize the domain state of the magnetic grains.

\subsubsection{Laboratory Redeposition and Compaction}

[17] The redeposition and compaction experiments were conducted on three specimens representing fine, medium, and coarse-grained sandstones. The specimens were first carefully disaggregated. To avoid magnetic contamination, specimens were wrapped in paper and crushed into small pieces with a rock. The disaggregated material was carefully examined under a light microscope to make sure that 


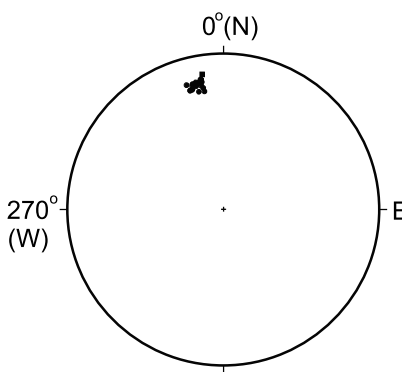

$180^{\circ}(\mathrm{S})$

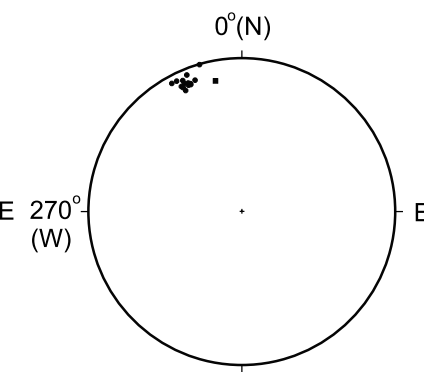

$180^{\circ}(\mathrm{S})$

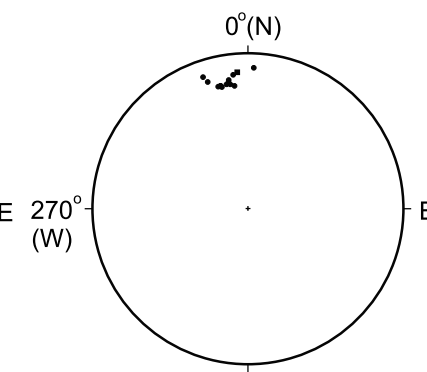

$180^{\circ}(\mathrm{S})$

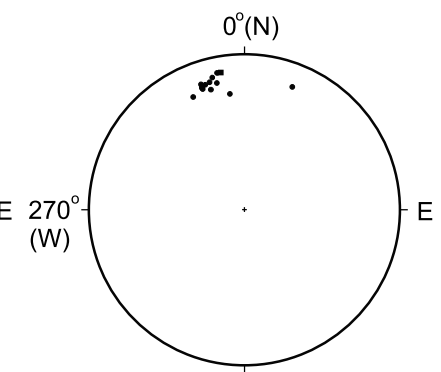

$180^{\circ}(\mathrm{S})$

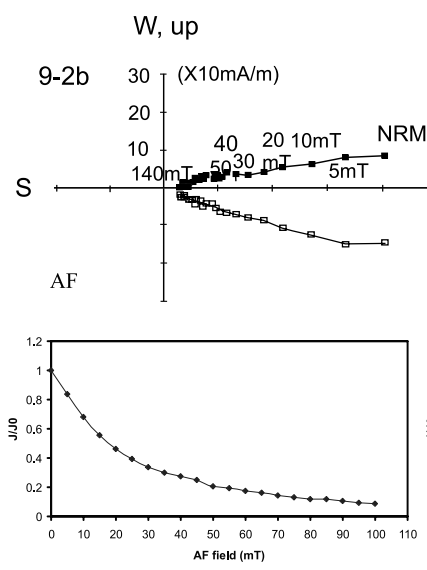

A
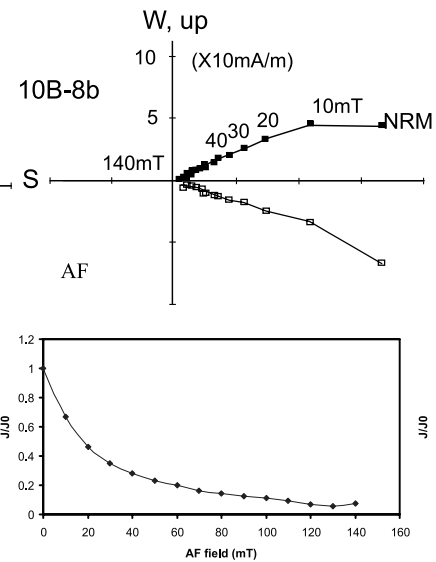

B

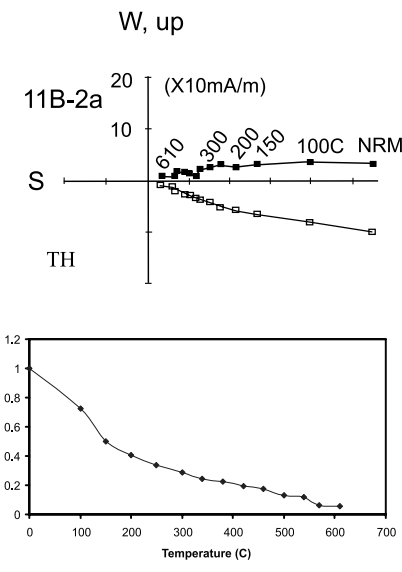

$\mathrm{C}$
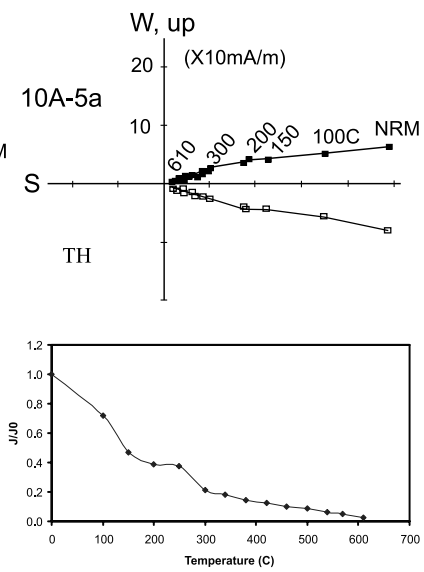

$\mathrm{D}$

Figure 2. Representative vector-end plots [Zijderveld, 1967] for alternating field (AF) and thermal (TH) demagnetization in stratigraphic coordinates. Solid squares indicate the horizontal components, and the open squares denote the vertical components.

the rock broke apart along the original grain boundaries. Water was then added to make a slightly oversaturated slurry that has a water content of $\sim 60 \%$ by weight. The slurry was stirred to make the mixture smooth and was subsequently dripped into a cylindrical plastic sample holder. The slurry sample was placed in the laboratory's $60^{\circ}$ inclination geomagnetic field for one hour to allow the sediments to settle and to acquire a depositional remanent magnetization (DRM), an analogue of natural processes of DRM acquisition. Then the slurry was compacted with a water tank consolidometer, as in previous laboratory compaction experiments [Anson and Kodama, 1987; Deamer and Kodama, 1990; Sun and Kodama, 1992; Kodama and Davi, 1995; Kodama, 1997; Tan and Kodama, 1998]. The remanence was measured before and during compaction. The volume loss of the sample and compaction pressures exerted by the water tank were monitored throughout the compaction process. Detailed laboratory preparation and compaction procedures can be found in Kodama and Davi [1995] and Kodama [1997].

[18] Subsequent to compaction, the samples were subjected to af demagnetization and their AMS and AAR were measured. These parameters were compared for the laboratory compacted samples and their corresponding natural samples to evaluate the burial compaction effect. An inclination correction was made following Jackson et al.'s [1991] approach, using the sample's AAR data and an estimate of individual particle anisotropy [Sun and Kodama, 1992; Kodama, 1997].

\subsection{Petrographic Observations}

[19] In order to determine whether any mineral alteration suggestive of remagnetization had occurred in our samples, thin sections were made from six coarse- to medium-grained sandstone samples by Spectrum Petrographics Inc. The thin sections were examined and photographed under a transmitted light microscope at magnifications of 100 to 400 times.

\section{Results}

\subsection{Paleomagnetic Results}

[20] The samples had natural remanent magnetization (NRM) intensities ranging from $20 \mathrm{~mA} / \mathrm{m}$ to $100 \mathrm{~mA} / \mathrm{m}$, typically around $60 \mathrm{~mA} / \mathrm{m}$. Both alternating field (af) and thermal demagnetization successfully isolated the characteristic remanence magnetizations (ChRMs), all of which display normal polarity remanence. Most af demagnetized samples showed single-component magnetizations (Figure 2a). The remaining af demagnetized samples exhibited double-component magnetizations with the lower coercivity component removed typically between $10 \mathrm{mT}$ to $20 \mathrm{mT}$ (Figure 2b). Almost all af demagnetized samples retained $\sim 10 \%$ of their initial NRM intensity after the af demagnetization experiments were completed at $\sim 130 \mathrm{mT}$, indicating the presence of high-coercivity remanence carriers in the samples. Thermal demagnetization proved to be more effective than af demagnetization in isolating the ChRMs since almost all remanence was lost when the 
Table 1. Paleomagnetic Results From the El Campito Section $\left(27.8^{\circ} \mathrm{N}, 114.9^{\circ} \mathrm{W}\right)$ of the Valle Group, Vizcaino Peninsula, Baja California, Mexico ${ }^{a}$

\begin{tabular}{|c|c|c|c|c|c|c|c|c|}
\hline \multirow[b]{2}{*}{ Site No. } & \multirow[b]{2}{*}{ Bedding S/D, deg } & \multirow[b]{2}{*}{$\mathrm{n} / \mathrm{N}$} & \multicolumn{2}{|c|}{ In Situ Mean } & \multicolumn{2}{|c|}{ Tilt Corrected } & \multicolumn{2}{|c|}{ Dispersion } \\
\hline & & & Dec, deg & Inc, deg & Dec, deg & Inc, deg & $\mathrm{k}$ & $\alpha_{95}$ \\
\hline $1 \mathrm{~A}$ & $288 / 59$ & $15 / 15$ & 298.0 & 49.0 & 335.7 & 17.0 & 56.9 & 5.1 \\
\hline 1B & $288 / 59$ & $13 / 13$ & 296.9 & 51.8 & 337.8 & 18.8 & 50.2 & 5.9 \\
\hline $2 \mathrm{~B}$ & $286 / 56$ & $11 / 15$ & 297.6 & 59.2 & 342.9 & 23.2 & 80.7 & 5.1 \\
\hline 3 & $286 / 56$ & $10 / 14$ & 304.6 & 49.8 & 336.7 & 14.9 & 105.5 & 4.7 \\
\hline 4 & $281 / 56$ & $9 / 14$ & 309.2 & 59.6 & 343.3 & 16.5 & 33.0 & 9.1 \\
\hline 5 & $288 / 50$ & $7 / 11$ & 295.4 & 50.6 & 333.7 & 25.7 & 145.7 & 5.0 \\
\hline 6 & $288 / 50$ & $10 / 12$ & 307.0 & 52.8 & 340.2 & 21.2 & 25.6 & 9.7 \\
\hline 7 & $288 / 50$ & $10 / 14$ & 310.7 & 51.6 & 340.8 & 18.7 & 94.7 & 5.0 \\
\hline 8 & $288 / 50$ & $10 / 10$ & 301.6 & 40.8 & 327.9 & 16.5 & 120.2 & 4.4 \\
\hline 9 & $288 / 50$ & $12 / 15$ & 312.6 & 59.8 & 348.1 & 23.3 & 69.6 & 5.2 \\
\hline $10 \mathrm{~A}$ & $284 / 50$ & $14 / 14$ & 314.2 & 61.6 & 347.6 & 22.5 & 114.4 & 3.7 \\
\hline $10 \mathrm{~B}$ & $284 / 50$ & $22 / 22$ & 320.2 & 60.6 & 349.1 & 19.7 & 96.0 & 3.2 \\
\hline $10 \mathrm{C}$ & $284 / 50$ & $13 / 13$ & 329.1 & 63.3 & 354.4 & 19.3 & 274.0 & 2.5 \\
\hline $11 \mathrm{~A}$ & $284 / 50$ & $10 / 10$ & 326.0 & 57.0 & 349.1 & 15.1 & 87.6 & 5.2 \\
\hline 11B & $284 / 50$ & $13 / 16$ & 328.0 & 59.0 & 350.6 & 16.3 & 51.0 & 5.9 \\
\hline 13 & $290 / 48$ & $7 / 10$ & 320.0 & 48.0 & 342.9 & 14.7 & 116.6 & 5.6 \\
\hline \multirow[t]{2}{*}{ Mean } & & 16 & 309.8 & 55.2 & & & 81.6 & 4.1 \\
\hline & & & & & 342.6 & 19.1 & 116.6 & 3.4 \\
\hline
\end{tabular}

${ }^{\text {a }} \mathrm{S} / \mathrm{D}$, strike/dip of bedding following the right-hand rule; $\mathrm{n} / \mathrm{N}$, number of samples used to calculate the mean ChRMs/number of demagnetized samples; Dec, declination; Inc, inclination; k, Fisher's [1953] precision parameter; $\alpha_{95}$, radius of circle of $95 \%$ confidence. All angles are in degrees.

maximum temperature of $610^{\circ} \mathrm{C}$ was reached (Figure $2 \mathrm{c}$ ). Thermally demagnetized samples generally displayed twocomponent magnetizations and the component with the lower unblocking temperatures was removed by $300^{\circ} \mathrm{C}$ (Figure 2d). As the demagnetization temperatures were incrementally increased to $610^{\circ} \mathrm{C}$, the magnetization decayed toward the origin, indicating a high-temperature component of remanence. The high unblocking temperature component magnetizations of samples generally agree with the ChRMs isolated by af demagnetization for samples from the same site, suggesting that demagnetization experiments were successful.
[21] Sixteen of the eighteen sites yielded ChRMs. These ChRMs were then used to calculate the mean direction for each site. Table 1 shows the site means for the 16 sites from the study area. Overall, these ChRM directions pointed toward the northwest with slightly scattered declinations and steep inclinations in geographic coordinates (Figure 3). Calculation of the mean of site means yielded an Inc $=55.2^{\circ}, \operatorname{Dec}=309.8^{\circ}, \alpha_{95}=4.1^{\circ}$, $\mathrm{N}=16$, in geographic coordinates and a mean of Inc $=$ $19.1^{\circ}$, Dec $=342.6^{\circ}, \alpha_{95}=3.4^{\circ}, \mathrm{N}=16$ in stratigraphic coordinates (Figure 3). The mean direction in geographic coordinates was different from that of the recent field at

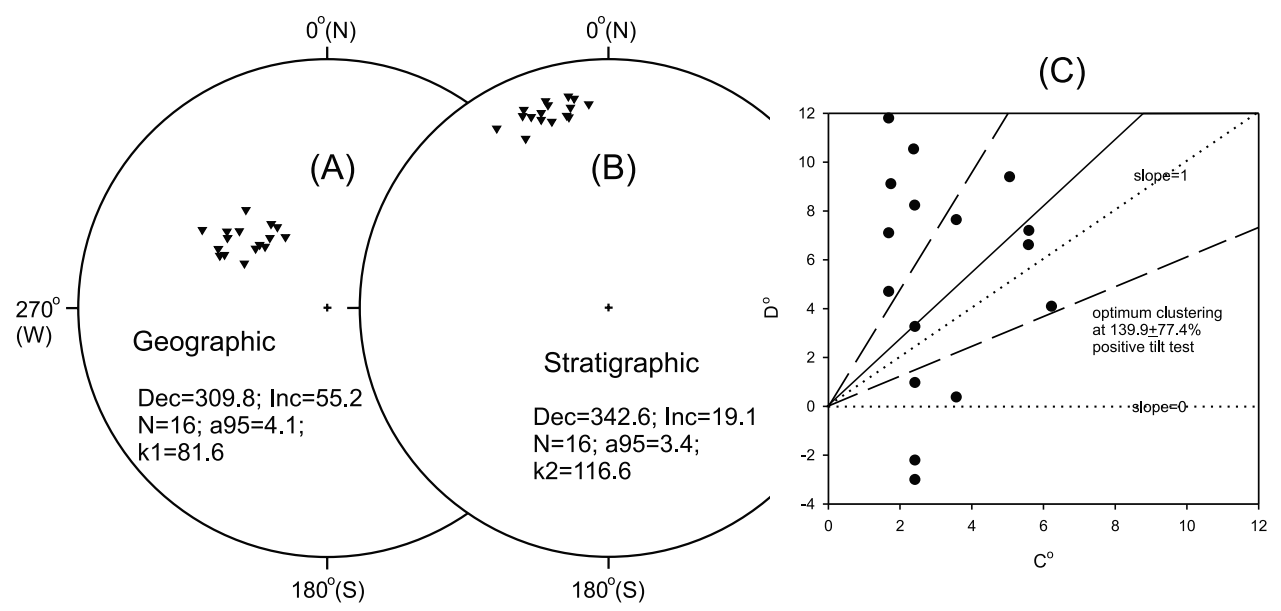

Figure 3. Equal area plots (lower hemisphere) showing site mean directions of the Valle samples at El Campito section in (a) geographic and in (b) stratigraphic coordinates. Structural correction slightly improved the clustering of directions with $\mathrm{k} 2 / \mathrm{k} 1=1.43$. (c) The direction-correction (DC) tilt test [Enkin, 2003 ] indicates that the optimal clustering occurs at $139.9 \pm 77.4 \%$ untilting, suggesting a pretilting remanence acquisition. All angles are in degrees. Symbols in Figure 3c are as follows: the solid line indicates the mean slope, and the area between two long-dashed lines indicates the $95 \%$ confidence region of the mean slope. 

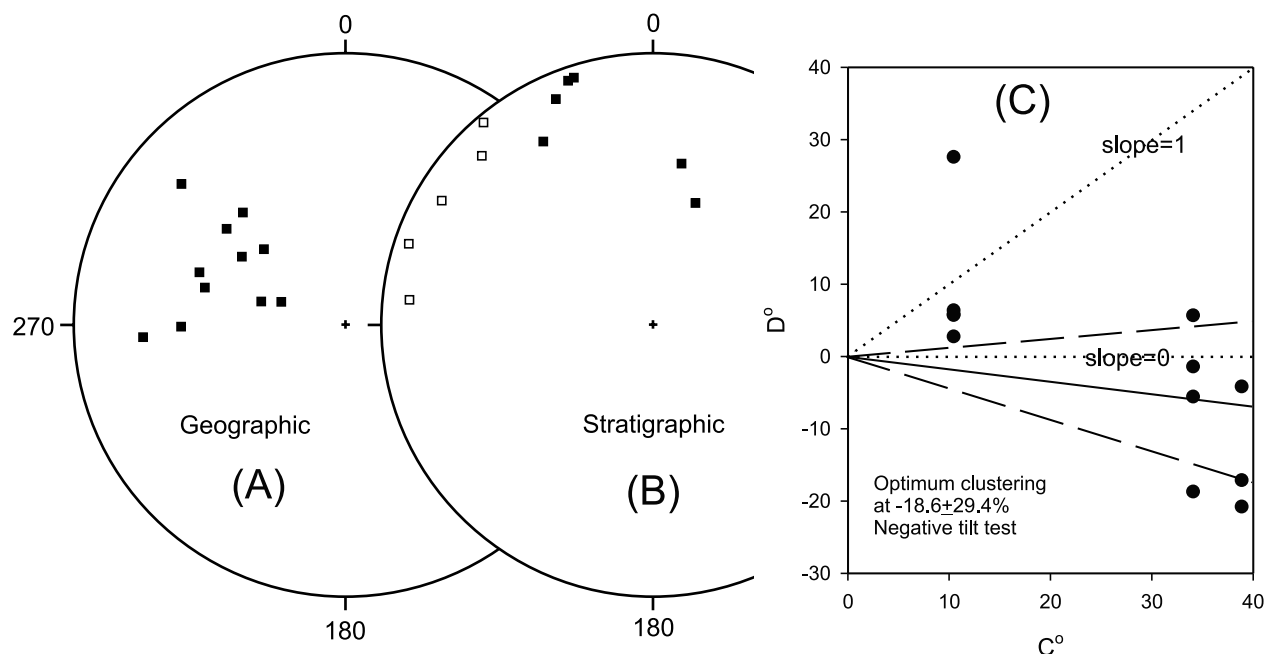

Figure 4. Equal area plots of characteristic directions of samples from a slump fold in (a) geographic coordinates and in (b) stratigraphic coordinates. The remanence directions become more dispersed after unfolding. (c) The DC test indicates that remanence was acquired after slumping. Solid squares indicate downward directions, and open squares indicate upper hemisphere projections.

the sampling site, which indicates that the remanence did not originate from recent overprinting. Because the sampled strata are consistently dipping toward the northeast at about $55^{\circ}$, the bedding tilt correction slightly improved clustering of the paleomagnetic site means $\left(\mathrm{k}_{2} / \mathrm{k}_{1}=1.43\right)$. The direction-correction (DC) tilt test [Enkin, 2003] indicates that the optimal clustering occurs at $139.9 \pm$ $77.4 \%$ untilting, suggesting a pretilting remanence acquisition. In order to constrain the timing of remanence acquisition, a fold test was performed for site $2 \mathrm{~A}$, which was sampled from the hinge and two limbs of a tight, soft sediment deformation slump fold. The remanence directions were dispersed after unfolding and the DC tilt test shows that the optimal clustering occurs at $-18.6 \pm$
29.4\% untilting (Figure 4), suggesting that the remanence acquisition postdates slumping.

[22] In order to further bracket the age of remanence, paleomagnetic data from this study and previous results from the Valle Group [Patterson, 1984; Hagstrum et al., 1985; Smith and Busby, 1993a] were combined to perform tilt tests. When the paleomagnetic data of the El Campito section from this study are combined with the El Campito data of Hagstrum et al. [1985] to perform a DC test, it is found that the optimal clustering occurs at $11.9 \pm 30.2 \%$ untilting (Figure 5), suggesting a posttilting acquisition of magnetization. When all paleomagnetic data from both El Campito and Cedros Island were utilized to perform a DC test, a positive regional tilt test results with optimum

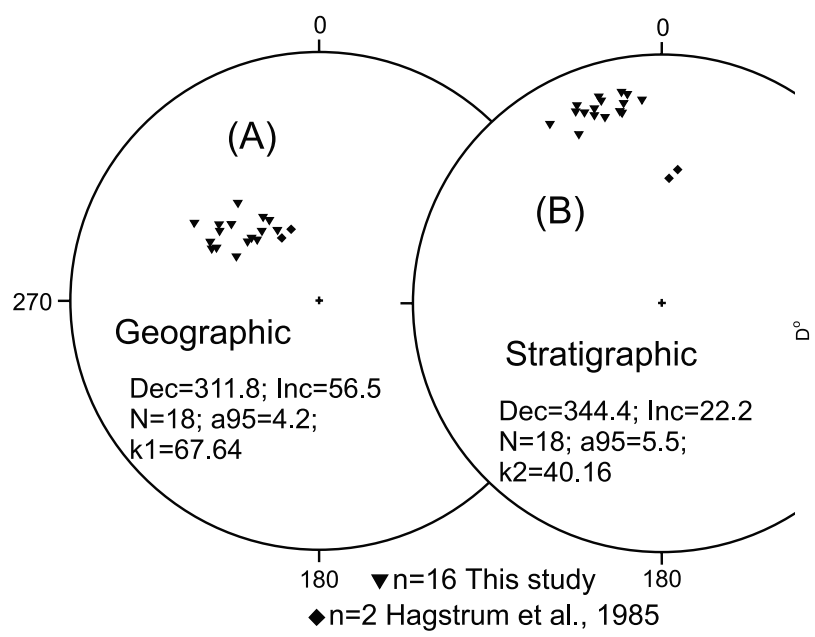

(C)

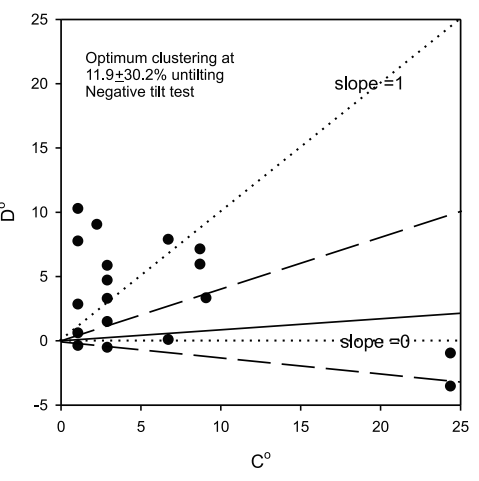

Figure 5. The remanence directions from the El Campito section of the Valle in (b) stratigraphic coordinates are more dispersed than those in (a) geographic coordinates. (c) The DC test suggests that remanence acquisition occurred after tilting. 

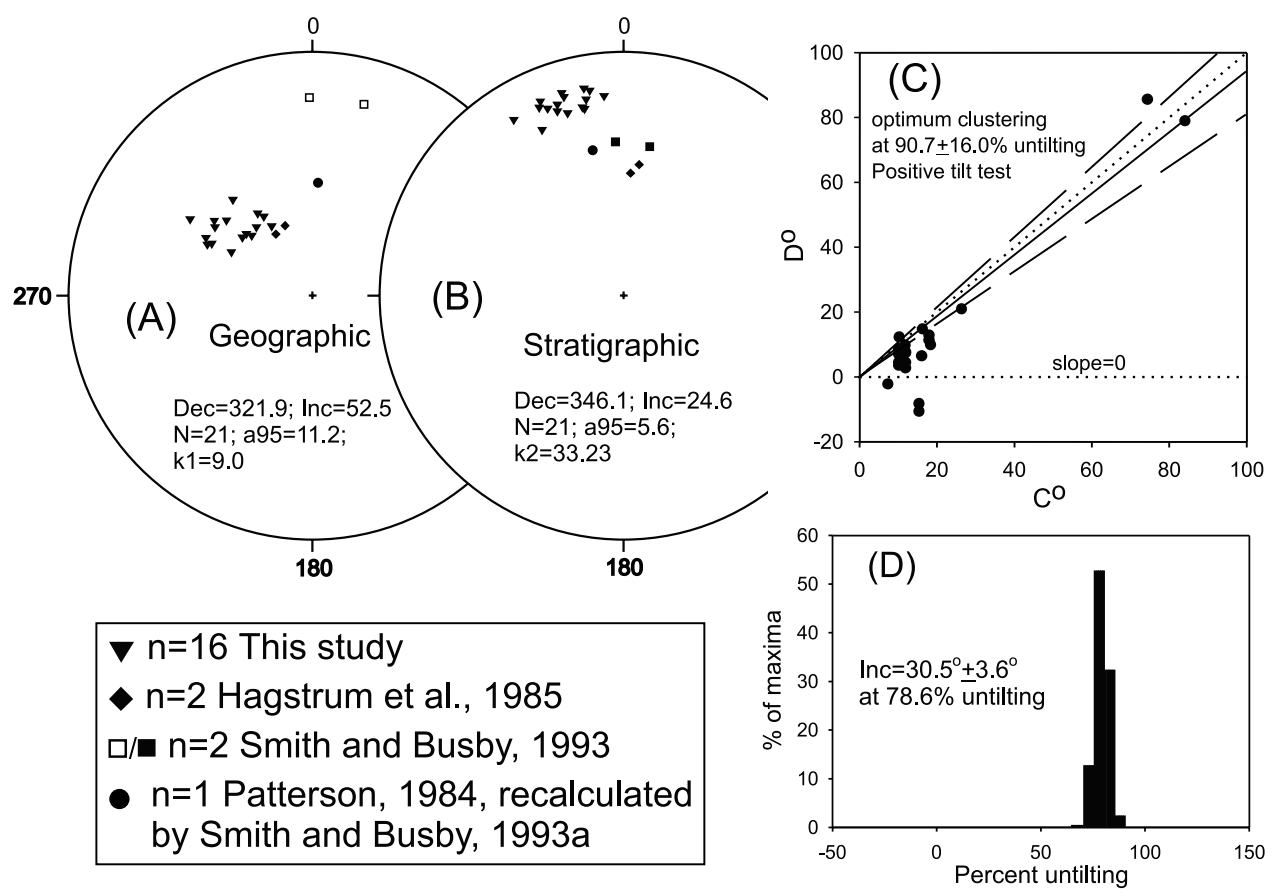

Figure 6. A regional tilt test using all paleomagnetic data from the Valle Group. Equal area plots of remanence directions (a) before and (b) after regional tilting show that the tilt-corrected directions are better grouped $(\mathrm{k} 2 / \mathrm{k} 1=3.7)$. Open squares indicate upper hemisphere projections. (c) The DC test is positive, suggesting that remanence was acquired before the regional tilting. (d) Fold test of inclinationonly using the formulation of Watson and Enkin [1993]. The histogram shows the distribution of the maxima of kappa from 1000 resamplings of original data as a function of stepwise untiting. The central $95 \%$ range of this distribution occurs between $100 \%$ and $0 \%$ untilting, suggesting a syntilting acquisition of remanence.

clustering at $90.7 \pm 16.0 \%$ untilting (Figures $6 \mathrm{a}, 6 \mathrm{~b}$, and $6 \mathrm{c}$ ). However, the Valle directions from Cedros Island and El Campito are distinct in stratigraphic coordinates (Figure 6b), suggesting that the bedding correction may be complicated by relative inclined- or vertical-axis rotations of blocks at the two localities. We, therefore, compare the mean inclinations only from the Valle Group strata from Cedros Island and El Campito to eliminate the effect of possible differential vertical-axis rotations on the fold test. The inclinationonly fold test [Waston and Enkin, 1993; Enkin and Watson, 1996] indicates that magnetization was acquired at $78.6 \%$ untilting $(+6.3 \%,-6.5 \%)$ with a mean inclination of $30.5^{\circ} \pm$ $3.6^{\circ}$ (Figure 6d).

\subsection{Rock Magnetic Results}

4.2.1. Magnetic Mineralogy, Grain Size, and Magnetic Fabrics

[23] IRM acquisition measurements were conducted on one specimen from each site. Almost all samples acquired a saturation magnetization at $\sim 200 \mathrm{mT}$, suggesting that the remanence primarily resides in low-coercivity ferrimagnetic minerals, probably magnetite. Thermal demagnetization curves of a composite IRM, which is acquired along orthogonal axes of the sample at different field values [Lowrie, 1990], show that the low-coercivity magnetic minerals dominate the samples and have unblocking temperatures between $550^{\circ} \mathrm{C}$ and $600^{\circ} \mathrm{C}$, indicative of magnetite. The sharp reversible drop at $\sim 570^{\circ} \mathrm{C}$ in high-temperature susceptibility measurements further suggest the presence of magnetite in samples (Figure 7a). The occurrence of the Verwey transition, though suppressed probably due to surface oxidation of magnetite particles [Özdemir et al., 1993], in the low-temperature measurements adds support that the low-coercivity phases are magnetite (Figure $7 \mathrm{~b}$ ). Thus magnetite is considered as the dominant magnetic phase in the samples. In addition, a trace amount of hematite may occur in the samples as well, because the composite IRMs were not totally removed until a temperature of $675^{\circ} \mathrm{C}$ was reached. Furthermore, the samples may contain small amounts of other magnetic phases, such as maghemite as suggested by the minor nonreversibility at temperatures below $550^{\circ} \mathrm{C}$ of the high-temperature thermomagnetic curves (Figure 7a).

[24] All hysteresis loops were corrected for paramagnetic contributions and all corrected loops close at fields less than $300 \mathrm{mT}$, which is consistent with the interpretation that magnetite is the dominant magnetic mineral. A few loops also display wasp-waistedness, though it is quite subtle, suggesting that different grain sizes of magnetite are probably present in the samples. When the hysteresis parameters are plotted on the Day plot [Day et al., 1977], the data appear in the pseudo-single domain (PSD) field (Figure 7c). The coercivity component analysis indicates that samples mainly contain two dominant coercivities, $\sim 10-15 \mathrm{mT}$ and $\sim 75-83 \mathrm{mT}$ 

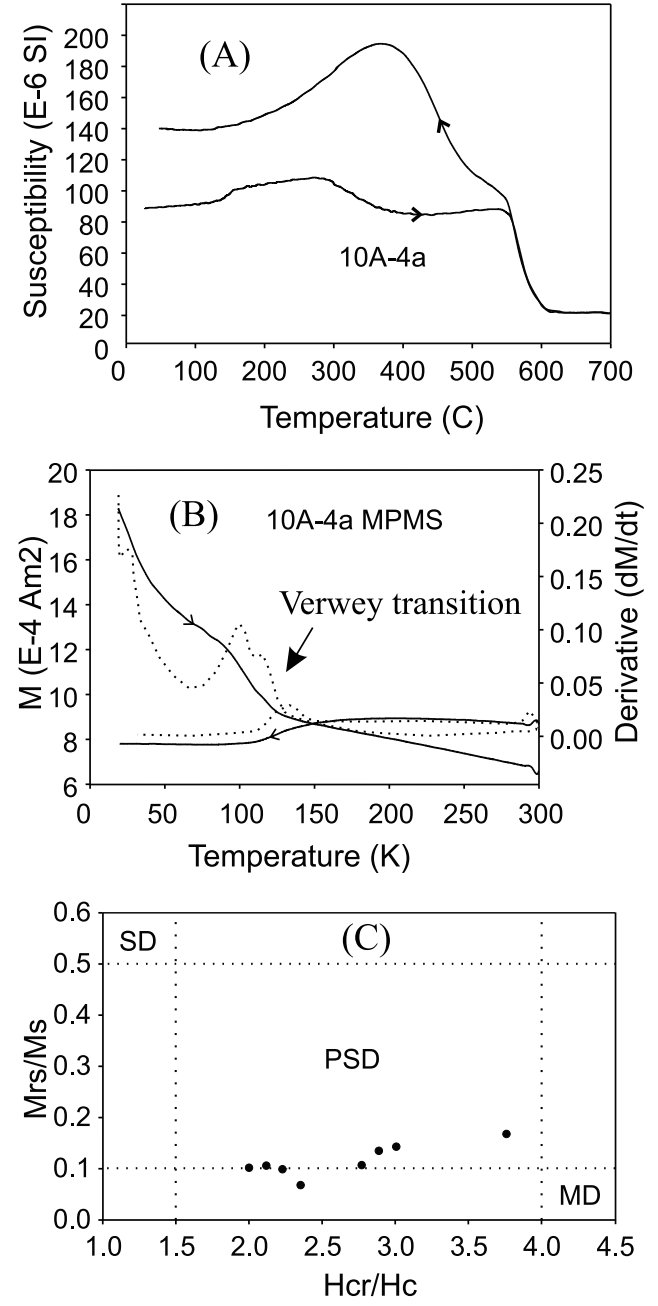

Figure 7. Rock magnetic properties of representative specimens. (a) High-temperature susceptibility curves show a sharp reversible drop at $\sim 570^{\circ} \mathrm{C}$, indicative of magnetite. The nonreversibility at temperatures below $\sim 550^{\circ} \mathrm{C}$ suggests the presence of other magnetic phases as well. (b) Low-temperature SIRM data display a subdued Verwey transition occurred at $\sim 120 \mathrm{~K}$, indicating the presence of magnetite that may be subjected to oxidation. (c) Hysteresis loop parameters plotted on a $\mathrm{Mrs} / \mathrm{Ms}$ versus $\mathrm{Hcr} / \mathrm{Hc}$ diagram [Day et al., 1977], showing that PSD grains reside in samples.

(Figure 8, Tables 2a and 2b). These two distinct coercivity components are interpreted as magnetite particles [Kruiver and Passier, 2001] of different grain size, with the lower coercivity component corresponding to MD grains and the higher coercivity corresponding to PSD grains. Because PSD grains contribute over $80 \%$ of remanence, the mixing of PSD grains with MD grains yield a resultant PSD domain state as shown in Day plot (Figure 7c). Thus MD and PSD magnetite are regarded as the major remanence carriers.

[25] AMS fabrics vary from site to site, but generally have minimum axes clustered nearly perpendicular to bedding, a fabric typical of depositional and/or compactional origin. Some sites exhibited minimum axes clustering about $10^{\circ}$ from the pole to bedding and maximum axes clustered about $10^{\circ}$ from the bedding plane, which implies that currents and/or initial bedding dip probably have affected the magnetization of these samples during deposition [Rees and Woodall, 1975]. The AMS data from the slump fold yield a negative fold test (Figure 9), indicating that magnetic fabrics must have been developed after the sediment slumping.

[26] The pARM curves display an asymmetric shape that has a maximum at about $30 \mathrm{mT}$. Because grains with coercivities greater than $30 \mathrm{mT}$ account for more than half of the total ARM and the fields used to isolate ChRMs were generally greater than $30 \mathrm{mT}$, the $30-100 \mathrm{mT}$ window was applied for the subsequent AAR measurements. The AAR measurements were made on 33 af demagnetized specimens and the results are plotted in Figure 10a. The minimum axes are in general centered at the pole to bedding and the maximum axes scattered in the horizontal. The plots of lineation (Kmax/Kint) versus foliation (Kint/Kmin) [Flinn, 1953] show that the AAR data are predominately oblate (Figure 10b). Because half of the specimens from the slump fold were thermally demagnetized, the limited number of specimens available for AAR from the slump fold inhibits us from performing a statistically meaningful fold test on its AAR data. However, the oblate magnetic fabrics are often considered to be the result of deposition and/or burial compaction; hence, the occurrence of oblate fabrics in AAR could suggest a primary origin for the remanence. Similar oblate fabrics have been identified in marine sediments from southern California [Kodama and Davi, 1995; Tan and Kodama, 1998], and have been used as an indicator of primary remanence.

\subsubsection{Sedimentologic Controls on Remanence 4.2.2.1. Compaction}

[27] Compaction experiments were conducted on three specimens representative of coarse, medium, and finegrained sandstones. Figure 10c shows the changes in inclination with volume loss during the compaction experiments. As the pressure increases, both the rate of inclination shallowing and the rate of volume loss decrease, suggesting that samples were not overpressured [Deamer and Kodama, 1990; Tan and Kodama, 1998]. The patterns of change in inclination shallowing and volume loss during compaction in this study are similar to those reported in previous compaction correction studies [Deamer and Kodama, 1990; Sun and Kodama, 1992; Kodama and Davi, 1995; Kodama, 1997; Tan and Kodama, 1998]. The AMS and AAR fabrics of compacted samples show typical oblate fabrics characterized by vertical minimum axes and horizontal maximum axes, and the compacted samples yielded magnetic fabrics similar to that of their corresponding natural samples. In addition, the bulk remanence anisotropy of compacted samples is similar to that of natural samples ranging from $\sim 3 \%$ to $\sim 6 \%$. The similarities in magnetic fabrics and bulk remanence anisotropy would suggest that the laboratory compaction experiments can serve as a good analogue of natural compaction processes.

[28] In all compaction runs, the inclinations declined by $\sim 10^{\circ}$ when the total volume loss was $20 \sim 27 \%$. The ChRMs of compacted samples were isolated after af demagnetization and the inclination of ChRMs can be 

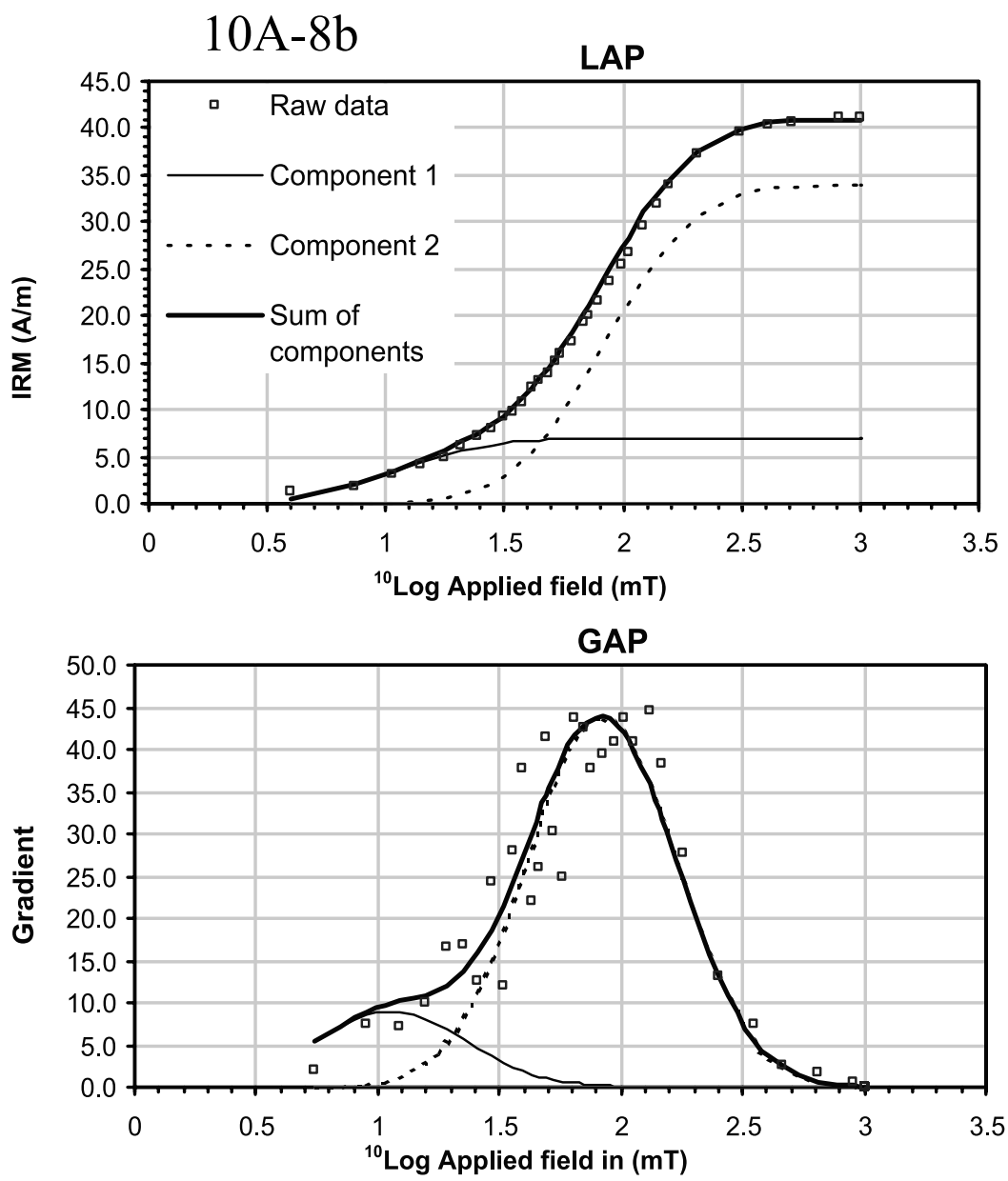

Figure 8. An example of IRM component analysis. LAP, linear acquisition plot; GAP, gradient acquisition plot [Kruiver et al., 2001]. The statistical test for this sample is shown in Table 2 a.

used to determine $a$, the anisotropy of individual magnetic particles, which is an important parameter required for an inclination correction. The $a$ value was derived from the following equation rewritten from Jackson et al. [1991]:

$$
a=\frac{\tan I_{C h R M}-\tan I_{o}}{q_{x}^{*} \tan I_{C h R M}-q_{z}^{*} \tan I_{o}}-2
$$

where, $I_{C h R M}$ is the inclination of the ChRMs; $I_{o}$ is inclination of the slurry (prior to compaction);

$$
q_{x}=\frac{A R M_{x}}{A R M_{x}+A R M_{y}+A R M_{z}} ; q_{z}=\frac{A R M_{z}}{A R M_{x}+A R M_{y}+A R M_{z}},
$$

where $A R M$ is the anhysteretic remanent magnetization. The resulting $a$ factors for coarse, medium, and fine-grained sandstone samples were $1.49,1.40$, and 1.43 , respectively. Assuming that compaction results in the development of oblate magnetic fabrics in sediments [Sun and Kodama, 1992], the remanence anisotropies of both the bulk sample

Table 2a. $F$ Test for a Two- or One-Component Fit of IRM Acquisition Data for Sample $10 \mathrm{~A}-8 \mathrm{~b}^{\mathrm{a}}$

\begin{tabular}{ccccccc}
\hline \hline 10A-8b & Component & SIRM, $\%$ & $\mathrm{~B}_{1 / 2}, \mathrm{mT}$ & Dp, mT & LAP & GAP \\
\hline Fit 1 & 1 & 17.1 & 11.2 & 2.0 & & \\
& 2 & 82.9 & 83.2 & 2.0 & $6.984 \mathrm{E}-01$ & $1.833 \mathrm{E}+03$ \\
Fit 2 & 1 & 100 & 70.8 & 2.6 & $1.961 \mathrm{E}+00$ & $4.133 \mathrm{E}+03$ \\
\hline \multicolumn{3}{r}{} & & LAP & & GAP \\
& Test Statistics & & 2.81 & 2.26 \\
& $F$ test & & fit 1 better & fit 1 better & \\
\hline \hline
\end{tabular}

${ }^{a}$ Critical $F$ value at the $95 \%$ confidence level for $\mathrm{N}=30$ is $1.8409 . \mathrm{B}_{1 / 2}, \mathrm{Bcr}$; Dp, dispersion parameter representing one standard deviation; LAP, linear acquisition plot; GAP, gradient acquisition plot [Kruiver et al., 2001]. 
Table 2b. Summary of the Two-Component IRMs for Six Representative Samples From the El Campito Section of the Valle Group

\begin{tabular}{|c|c|c|c|c|c|c|}
\hline \multirow[b]{2}{*}{$\underline{\text { Sample No. }}$} & \multicolumn{3}{|c|}{ Component 1} & \multicolumn{3}{|c|}{ Component 2} \\
\hline & Contribution, $\%$ & $\mathrm{~B}_{1 / 2}, \mathrm{mT}$ & $\mathrm{Dp}, \mathrm{mT}$ & Contribution, $\%$ & $\mathrm{~B}_{1 / 2}, \mathrm{mT}$ & $\mathrm{Dp}, \mathrm{mT}$ \\
\hline $2 \mathrm{~A}-2 \mathrm{a}$ & 19.6 & 12.6 & 2.8 & 80.4 & 74.1 & 2.2 \\
\hline $4-8$ & 16.7 & 10.0 & 2.5 & 83.3 & 75.9 & 2.3 \\
\hline $7-3 a$ & 17.5 & 11.2 & 2.5 & 82.5 & 72.4 & 2.5 \\
\hline $10 \mathrm{~A}-8 \mathrm{~b}$ & 17.1 & 11.2 & 2.0 & 82.9 & 83.2 & 2.0 \\
\hline $10 \mathrm{C}-8 \mathrm{a}$ & 17.0 & 11.2 & 2.8 & 83.0 & 83.2 & 2.3 \\
\hline $11 B-4 b$ & 16.2 & 15.8 & 3.2 & 83.8 & 83.2 & 2.3 \\
\hline
\end{tabular}

and the individual grain can be used to determine the compaction-induced inclination shallowing by following Jackson et al.'s [1991] inclination correction approach [Kodama, 1997]. The graphical presentation of this inclination correction technique is shown in Figure 10d. The combination of AAR data and $a$ factors for each of three representative samples indicates that compaction caused only $7.5^{\circ}$ of inclination shallowing for the Valle sediments at El Campito. This value is less than the $\sim 14^{\circ}$ inclination shallowing determined for the Pigeon Point Formation [Kodama and Davi, 1995], the $\sim 11^{\circ}$ shallowing obtained from the Ladd Formation [Tan and Kodama, 1998], and the $\sim 17^{\circ}$ inclination shallowing observed for the Point Loma Formation [Tan and Kodama, 1998], but similar to that $\left(8^{\circ}\right)$ observed for the Nacimiento Formation [Kodama, 1997]. The compaction correction yielded a mean corrected direction of Dec $=346.3^{\circ}, \mathrm{Inc}=26.6^{\circ}, \mathrm{N}=33$, $\alpha_{95}=4.0^{\circ}$ for the middle Cretaceous El Campito section of the Valle Group.

\subsubsection{Grain Size and/or Clay Content Effect on} Inclination

[29] Samples from graded beds allow us to test whether the grain size and/or clay content can affect the amount of inclination shallowing. Because the coarser-grain layer presumably contains less clay than do the finer-grained layers, it is not possible to quantitatively differentiate the effect of grain size and clay content on inclinations. Three sites were collected. Sites $10 \mathrm{~A}$ and $10 \mathrm{~B}$ are from the bottom and top of a graded bed, respectively; Site 10C is from a very similar, but finer-grained bed immediately below the bed where Sites $10 \mathrm{~A}$ and $10 \mathrm{~B}$ were sampled. Therefore Sites 10A, 10B, and 10C represent coarse-, medium-, and fine-grained samples respectively. Paleomagnetic data from these three sites show statistically indistinguishable directions (Table 3) (Figure 11). This may indicate that either grain size/clay content over the range represented by these samples does not influence the amount of inclination shallowing or the magnetic recorders were reset by a later remagnetization regardless of the differing grain size and clay contents of the beds.

\subsection{Petrographic Results}

[30] Several samples were selected for petrographic study. In general, the samples range from lithic arkose to feldspathic litharenite (classification of McBride [1963]) with the majority of lithic fragments of intermediate to silicic volcanic origin. There is also a significant proportion of hypabyssal rock fragments in the coarser samples. Plagioclase is the dominant feldspar in the samples. Other detrital minerals, occurring in low abundance, include biotite, amphibole, and epidote. The matrix locally includes both detrital fines and pseudomatrix derived from the breakdown
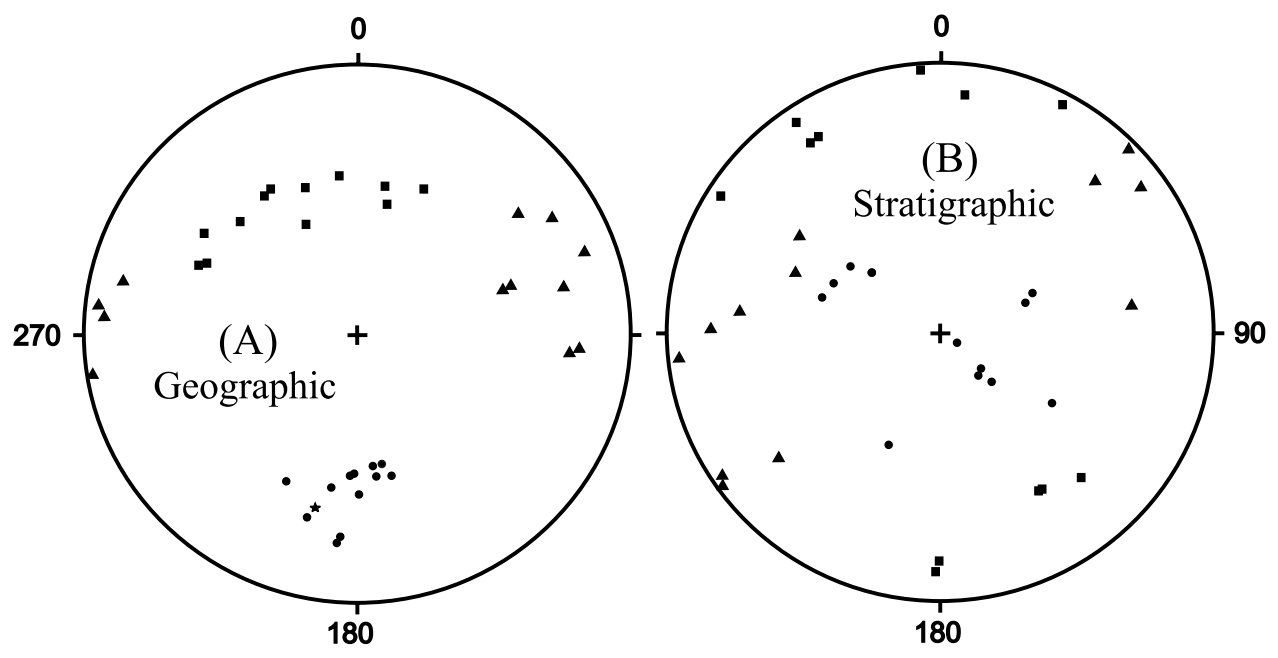

Figure 9. Equal area plots of the principal axis directions of the anisotropy of magnetic susceptibility (AMS) in (a) geographic coordinates and in (b) stratigraphic coordinates. The grouping of principal axes decreases after unfolding and provides a negative DC test with optimum clustering occurring at $8.0 \pm$ $21.7 \%$ untilting, indicating that the magnetic fabrics were developed after slumping. Squares indicate maximum axes, triangles indicate intermediate axes, and circles stand for minimum axes. The asterisk indicates the pole to beds stratigraphically above and below the slump fold. 

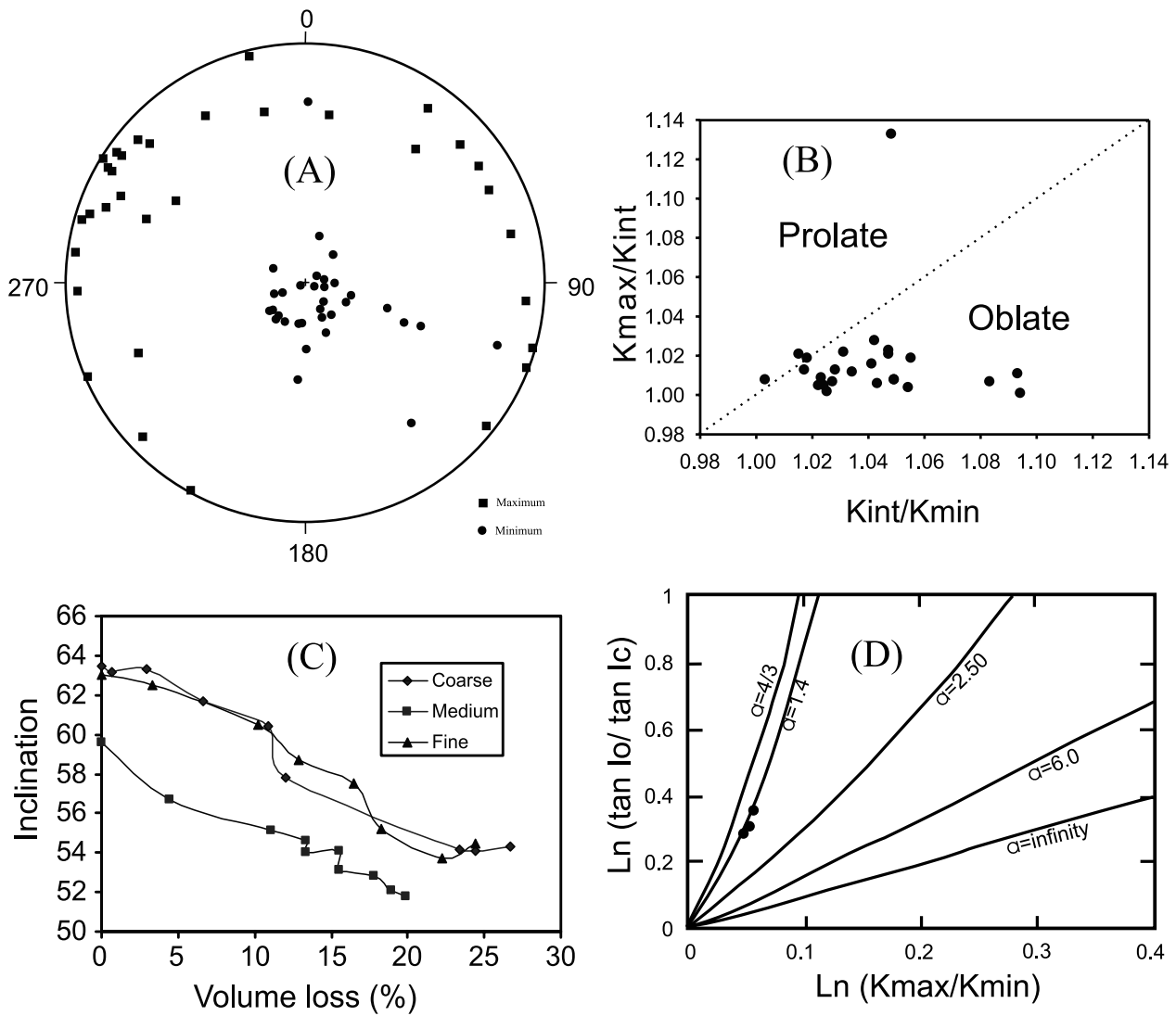

Figure 10. (a) Equal area plot (lower hemisphere) showing the maximum and minimum principal axis directions of the anisotropy of anhysteretic remanence (AAR) in stratigraphic coordinates. In general, minimum axes are perpendicular to bedding, and maximum axes lie in the bedding, typical of oblate fabrics. (b) Flinn diagram [Flinn, 1953] showing that oblate fabrics are dominant. (c) Inclination versus volume loss plot for the laboratory compaction experiments conducted with the disaggregated samples that represent coarse-, medium-, and fine-grained sandstones. (d) Graphic presentation of inclination correction technique [Jackson et al., 1991; Kodama, 1997]. The data indicate that compaction can explain only $\sim 7.5^{\circ}$ of the inclination shallowing.

of unstable volcanic grains during compaction. Carbonate minerals locally occur as a pore filling cement and as partial replacement of feldspar. The presence of plagioclase and biotite suggests that the El Campito rocks may have not undergone significant diagenetic alteration; however, the petrographic data do show that, overall, the mineral grains are not pristine. The boundaries of many detrital grains are nondistinct, rather than sharply defined, which could be due to postdepositional chemical alteration along the grain boundaries. Opaque phases are abundant in the samples. Some opaque minerals, probably magnetite, occur in the fractures and cracks of the mafic phases (Figure 12a). Most detrital opaque grains have light brownish rims (Figure 12b), suggesting diagenetic alteration. Some detrital grains have been replaced by calcite, but their original grain boundaries are still recognizable (Figure 12c). In some cases, the original minerals cannot be recognized because these minerals have been altered into cloudy, fuzzy, light brownish phases (Figure 12d), probably hematite and clay minerals. Occasionally, opaque inclusions are locally present within the cloudy and light brownish phases.

\section{Discussion}

[31] Our initial goals were to determine whether or not the paleomagnetic records of the Cretaceous marine sedi-

Table 3. Grain Size Distribution and Paleomagnetic Directions (in Stratigraphic Coordinates) of Samples From Graded Beds

\begin{tabular}{|c|c|c|c|c|c|c|c|c|c|c|}
\hline \multirow[b]{2}{*}{ Graded Sandstone } & \multicolumn{5}{|c|}{ Grain Size $(\Phi)$ Distribution, \% } & \multicolumn{5}{|c|}{ Directions in Stratigraphic Coordinates } \\
\hline & $<4^{\mathrm{a}}$ & $4-3$ & $3-2$ & $2-1$ & $>1$ & Dec, deg & Inc, deg & $\mathrm{n}$ & $\alpha_{95}, \operatorname{deg}$ & $\mathrm{k}$ \\
\hline Coarse-grained & 6.4 & 13.4 & 39.5 & 24.8 & 15.9 & 347.6 & 22.5 & 14 & 3.7 & 114.4 \\
\hline Medium-grained & 7.0 & 14.2 & 31.7 & 29.4 & 17.6 & 349.1 & 19.7 & 22 & 3.2 & 96.0 \\
\hline Fine-grained & 15.3 & 26.4 & 21 & 25.5 & 11.8 & 354.4 & 19.3 & 13 & 2.5 & 274.0 \\
\hline Mean & 9.5 & & & & & 350.4 & 20.5 & 3 & 5.7 & 460.9 \\
\hline
\end{tabular}

${ }^{a}$ Weight percentage of grains with size $<4 \Phi$ is considered as the estimate of clay content. 


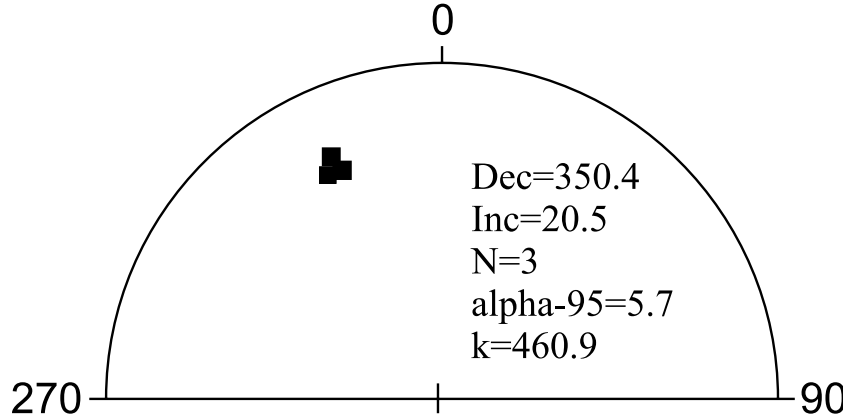

Figure 11. Site means of three sites representing coarse-, medium-, and fine-grained sandstones. The directions are statistically indistinguishable. See text or Table 5 for interpretation.

ments from the Vizcaino Peninsula in Baja California were biased by burial compaction and to correct for compactioncaused inclination shallowing, if any was discovered. The paleomagnetic, rock magnetic, and petrographic results from this study, however, showed that the origin of remanence in the Valle Group, Baja California, is far from simple. Af and thermal demagnetization successfully isolated high-quality ChRMs from 16 sites. The sixteen site means yielded a mean of Dec $=342.9^{\circ}$, Inc $=19.1^{\circ}, \alpha_{95}=$ $3.4^{\circ}$ in stratigraphic coordinates. This inclination is shallower by $18.9^{\circ}$ than the previously reported shallow inclination of $38^{\circ}$ from the Valle Group strata at nearby Cedros Island [Smith and Busby, 1993a] and it is the shallowest inclination among all the paleomagnetic data from the Valle Group (Table 4).

[32] The interpretation of the shallow inclinations is complicated due to the lack of tight constraints on the timing of remanence acquisition. Fold tests of the remanence of the Valle rocks indicate all possibilities of the timing of remanence acquisition (pre-, syn-, and posttilting) (Table 5). The DC test [Enkin, 2003] on both the remanence and the AMS of the slump fold are negative (Figures 4 and 9), suggesting that remanence acquisition postdates soft sediment slumping and the fabrics were developed after slumping. Regional tilt tests failed to provide tight constraints on the timing of remanence acquisition. The paleomagnetic data from the El Campito locality (our data and Hagstrum et al., 1985) constitutes a negative DC tilt test (Figure 5), suggesting that the remanence may have been acquired after the beds were tilted; however, all the paleomagnetic data from the Valle Group (our data + Hagstrum et al., $1985+$ Smith and Busby, 1993a) show a positive DC tilt test (Figure 6c), implying that the remanence acquisition predates the regional tilt. In addition, the inclination-only fold test of the data from the Valle Group, which eliminates complications caused by possible vertical-axis rotation between localities after remanence acquisition, indicates that the magnetization was acquired during tilting (Figure 6d). Therefore the remanence acquisition could have occurred almost anytime after slumping and during the deformation represented by the regional tilt test. The rock magnetic and petrographic evidence is not definitive and suggests that both primary and secondary magnetizations are possible (Table 5).
[33] An early acquisition of remanence is suggested by the presence of both AMS and AAR oblate fabrics with foliations parallel to bedding, which are often considered to be depositional and/or compactional in origin [e.g., Tarling and Hrouda, 1993; Sun and Kodama, 1992; Kodama and Davi, 1995; Tan and Kodama, 1998]. Also, the petrographic data show that the samples contain detrital magnetic grains and no obvious secondary magnetic grains. The shallow inclinations of a primary remanence of the middle Cretaceous El Campito rocks could result from either burial compaction or tectonic displacements. However, a compaction correction only explains $7.5^{\circ}$ of the inclination shallowing (Figure 10d), so the compaction-corrected inclinations would indicate that the Vizcaino Terrane lay $\sim 2700 \pm 400 \mathrm{~km}$ south of its present position at $\sim 95 \mathrm{Ma}$ and underwent northward displacement afterward. Since the paleomagnetic data of the lower Cretaceous Perforada Formation indicate that the Vizcaino terrane was located $\sim 1100 \pm 800 \mathrm{~km}$ south of its present location at $\sim 115 \mathrm{Ma}$ [Vaughn et al., 2004], a southward-then-northward translation would be required. A similar tectonic history has been inferred from the Churn Creek Formation of Baja British Colombia where the paleomagnetic data yield positive stability tests and suggest that Baja B.C. was formed $\sim 850 \pm 500 \mathrm{~km}$ south of its present position at $\sim 100-105 \mathrm{Ma}$, but lay $\sim 3050 \pm 450 \mathrm{~km}$ to the south at $\sim 95-85 \mathrm{Ma}$ [Enkin et al., 2003]. The striking similarity in the timing and magnitude of the terrane displacement inferred from the Churn Creek Formation and the Valle Group may indicate terrane displacement along a

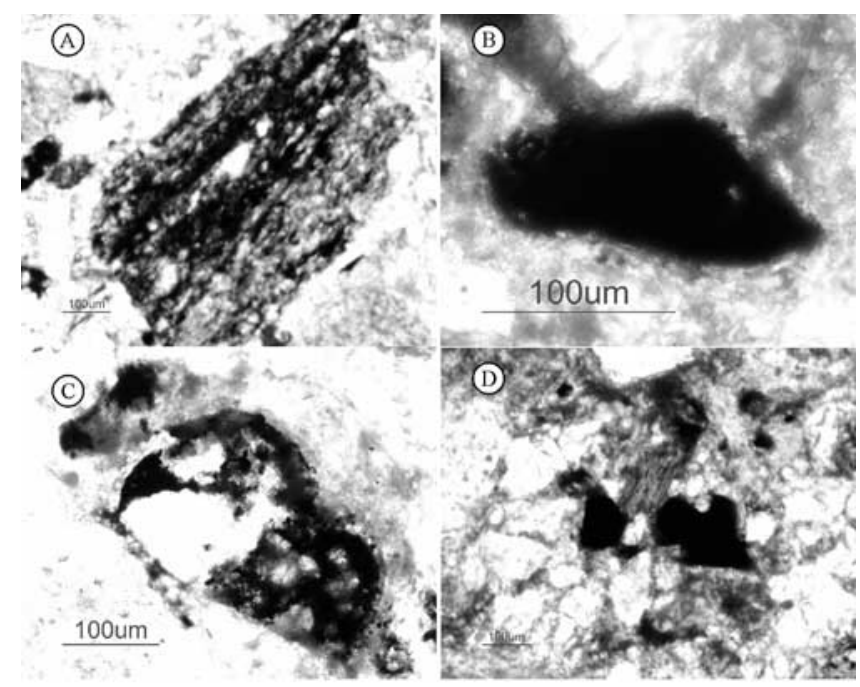

Figure 12. Representative photographs of thin sections showing features of mineralogical alteration in the El Campito samples. (a) Opaque phases, probably magnetite, occur along one set of cleavage of the biotite grains. This feature may suggest that mafic phases could have been partially altered into magnetic minerals. (b) Light brownish rims often appear at the detrital grain boundaries, indicating chemical alteration after deposition. (c) An assembly of different phases that appear to be the product of one detrital grain by chemical alteration. (d) The detrital minerals have been altered into the light brownish, cloudy, fuzzy phases that form the matrix and sometimes contain inclusions of opaque phases. See color version of this figure in the HTML. 
Table 4. Summary of Paleomagnetic Data From the Vizcaino Terrane ${ }^{\mathrm{a}}$

\begin{tabular}{|c|c|c|c|c|c|c|c|c|}
\hline Locality & Lat/Long, deg & Formation & Age & Inc/Dec & $\mathrm{N}(\mathrm{n})$ & $\alpha_{95}$ & P.Lat, deg & $\operatorname{Ref}^{b}$ \\
\hline El Campito & $27.8 / 245.1$ & Valle Group & Cenomanian ( 95 Ma) & $19.1 / 342.6$ & 16 & 3.4 & $9.8 \pm 2.6$ & 1 \\
\hline Cedros Island & $28.2 / 244.8$ & Valle Group & Albian-Coniacian & $38.0 / 2.8^{\mathrm{c}}$ & $(10)$ & 6.1 & $20.9 \pm 5.4$ & 2 \\
\hline Cedros Island & $28.2 / 244.8$ & Pinos Formation & Albian-Coniacian & $33.0 /$ & (24) & 6.0 & 18.0 & 2 \\
\hline El Campito & $27.8 / 245.2$ & Valle Group & Cenomanian (?) & $46.8 / 5.1$ & (12) & 4.0 & $28.0 \pm 4.1$ & 3 \\
\hline Vizcaino & $27.5 / 245.7$ & Valle Group & Cenomanian-Coniacian & $39.7 / 1.8$ & 6 & 6.1 & $22.5 \pm 5.7$ & 4 \\
\hline Vizcaino & $27.4 / 245.2$ & Perforada & Aptian ( 115Ma) & $47.3 / 310.9$ & 11 & 8.9 & $28.5 \pm 9.3$ & 5 \\
\hline North America & & & & $57.8 / 341.9$ & & 3.2 & $38.5 \pm 4.0$ & 6 \\
\hline
\end{tabular}

${ }^{\mathrm{a}}$ Inc, inclination; Dec, declination; N(n), number of sites (samples); $\alpha_{95}$, radius of circle of $95 \%$ confidence; P.Lat, paleolatitude; Lat/Long, latitude/ longitude; Ref, reference. All angles are in degrees.

${ }^{b} 1$, this study; 2, Smith and Busby [1993a]; 3, Hagstrum et al. [1985]; 4, Patterson [1984]; 5, Vaughn et al. [2004]; 6, the Early and mid-Cretaceous pole $\left(71.5^{\circ} \mathrm{N}, 194.9^{\circ} \mathrm{E}, \mathrm{A}_{95}=4.0^{\circ}\right)$ of Dickinson and Butler [1998] was used for calculation.

${ }^{\mathrm{c}}$ Recalculated from VG1 and VG2 of Smith and Busby [1993a] at sample level.

margin-parallel fault in a similar sense and by a comparable amount. However, the lack of a southward driving force from plate tectonic reconstructions of the Pacific basin [Engebretson et al., 1985] makes this model unsatisfactory. It is noteworthy that this model could be alternatively explained by terrane juxtaposition in a fold and thrust belt where a more displaced terrane is thrust over a less displaced one. However, the Perforada Formation is comformably overlain by the upper section of the Valle and a large-scale thrust fault system has not been discovered between the Perforada Formation and the upper section of the Valle. Another possibility is the influence of bottom currents on the remanence acquisition of Valle Group submarine fan deposits. Bottom currents may explain the difference in inclinations between the El Campito section and the other Valle results [Rees, 1961], however, our present knowledge does not allow us to quantify the bottom current effect on remanence. A third possibility is nondipolar geomagnetic field behavior or rapid true polar wander [Mahoney et al., 2001]. Assuming a primary remanence for the Valle Group rocks causes additional seemingly intractable problems, so a remagnetization interpretation may be more likely.

\section{Remagnetization}

[34] Remagnetization is suggested by post- and syntilting fold tests (Figures 5 and $6 \mathrm{~d}$ ) and petrographic data that show some alteration along the grain boundaries (Figure 12).
Also, the almost identical paleomagnetic directions observed in different grain size samples at Sites 10A, 10B, and $10 \mathrm{C}$ suggest that the rocks have likely been remagnetized (Figure 11). Perhaps the most likely interpretation of the results summarized in Table 5 is a secondary magnetization carried by the El Campito rocks. In this case, of course, tilt correction for the remagnetized rocks with their present bedding attitudes would give anomalously shallow inclinations.

\subsection{Timing of Remagnetization}

[35] Fold tests provide the age of remanence acquisition with respect to a tilting event. The timing of deformation events, however, are poorly known in the study area and may be constrained by the geological data. At the El Campito section, no younger strata were seen overlying the Valle beds, but the overlying Miocene beds of the Tortugas Formation to the south of the town of Bahia Tortugas, which is near El Campito on the Vizcaino peninsula, dip $\sim 25^{\circ}$ to the southwest, suggesting that two phases of deformation may have occurred in the El Campito region. Therefore it is possible that remagnetization occurred after the first episode of tilting and before the secondary deformation that tilted the Miocene beds, resulting in a syntilting acquisition of remanence as indicated by the inclination-only fold test.

[36] In order to better constrain the timing of the remagnetization, one approach is to remove the second phase

Table 5. Summary of Paleomagnetic, Petrographic, and Rock Magnetic Data Constraining the Age of Remanence

\begin{tabular}{|c|c|}
\hline Data & Interpretation \\
\hline & \\
\hline 1. Slump fold test fails & Postslumping remanence \\
\hline 2. Local tilt test fails & Posttilting remanence \\
\hline 3. Regional tilt test passes & Pretilting remanence \\
\hline 4. Inclination-only fold test & Syntilting remanence \\
\hline \multirow[t]{2}{*}{$\begin{array}{l}\text { 5. Almost identical directions of different grain size } \\
\text { samples }\end{array}$} & $\begin{array}{c}\text { Primary (?): grain size does not control compaction effect. } \\
\text { Secondary (?): magnetization was reset by remagnetization regardless } \\
\text { of grain size. }\end{array}$ \\
\hline & \\
\hline $\begin{array}{l}\text { 1. Detrital magnetic grains, no obvious secondary } \\
\text { magnetic grains }\end{array}$ & Primary (?) \\
\hline \multirow[t]{2}{*}{ 2. Alterations at the edges of detrital grains } & Secondary (?) \\
\hline & \\
\hline $\begin{array}{l}\text { 1. Both AMS and AAR fabrics with bedding-parallel } \\
\text { foliations }\end{array}$ & Primary (?) \\
\hline 2. Bimodal distribution of magnetic grain sizes & Secondary (?) \\
\hline
\end{tabular}




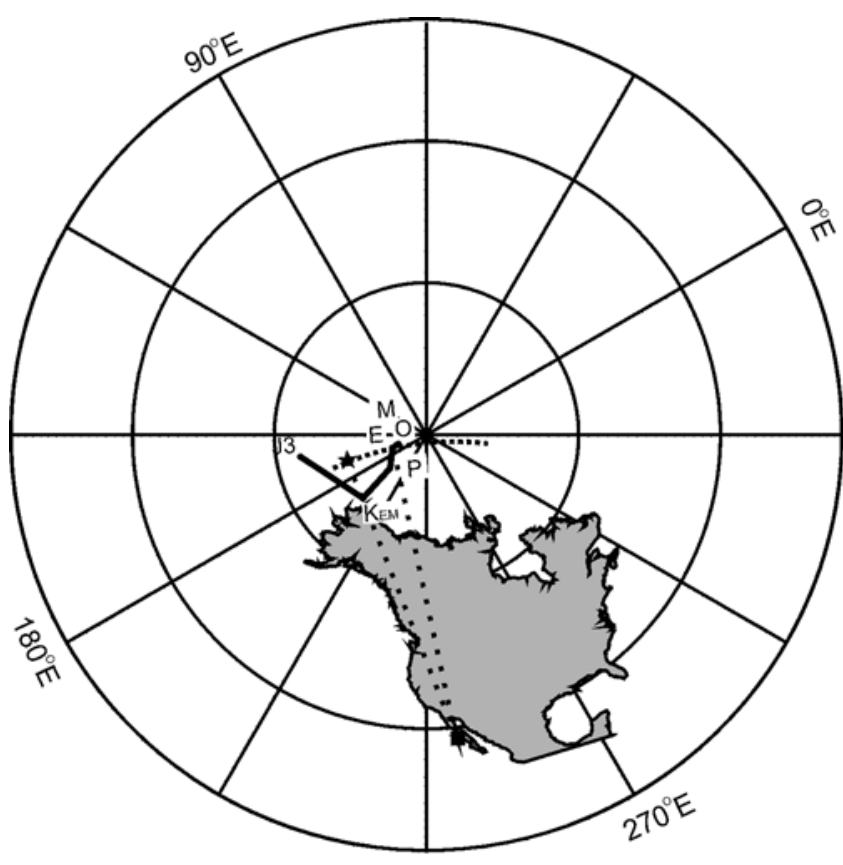

Figure 13. Virtual Geomagnetic Pole (asterisk) of the Campito of Valle with respect to the Cretaceous-Cenozoic segment of apparent polar wander path (APWP) of North America after the removal of the second phase (postMiocene) of tilting. The paleopole does not lie on the APWP of North America, but a small circle centered on the sampling site with a radius equal to the colatitude of the data intersects the North American APWP, indicating a $13.5^{\circ} \pm 5.4^{\circ}$ clockwise rotation with no significant latitudinal displacement since the late Cenozoic. The clockwise rotation is with respect to the mean $\left(84.9^{\circ} \mathrm{N}, 163.2^{\circ} \mathrm{E}, \mathrm{A}_{95}=4.4^{\circ}\right)$ of the Eocene, Oligocene, and Miocene reference poles of North America. J3, Late Jurassic $\left(61.5^{\circ} \mathrm{N}, 159.8^{\circ} \mathrm{E}, \mathrm{A}_{95}=4.8^{\circ}\right)$; $\mathrm{K}_{\mathrm{EM}}$, early and mid-Cretaceous $\left(71.5^{\circ} \mathrm{N}, 194.9^{\circ} \mathrm{E}, \mathrm{A}_{95}=\right.$ $\left.4.0^{\circ}\right)$; P, Paleocene $\left(81.5^{\circ} \mathrm{N}, 192.6^{\circ} \mathrm{E}, \mathrm{A}_{95}=3.2^{\circ}\right)$; E, Eocene $\left(82.8^{\circ} \mathrm{N}, 170.4^{\circ} \mathrm{E}, \mathrm{A}_{95}=3.0^{\circ}\right) ; \mathrm{O}$, Oligocene $\left(84.0^{\circ} \mathrm{N}\right.$, $168.4^{\circ} \mathrm{E}, \mathrm{A}_{95}=4.0^{\circ}$ ) (see Dickinson and Butler [1998] for references to paleopoles); M, Miocene $\left(87.4^{\circ} \mathrm{N}, 129.7^{\circ} \mathrm{E}\right.$, $\mathrm{A}_{95}=3.0^{\circ}$ ) [Hagstrum et al., 1987]; The square indicates the sampling locality $\left(27.8^{\circ} \mathrm{N}, 245.1^{\circ} \mathrm{E}\right)$.

(post-Miocene age) of deformation and calculate the resulting paleopole corresponding to the remanence direction for comparison to the North America pole path. A correction for the in situ directions from the El Campito was performed using an average bedding attitude (Strike $=131^{\circ}$, Dip $=$ $22^{\circ} \mathrm{S}$ ) of the Miocene Tortugas Formation located to the south of the town Bahia Tortugas. The corrected directions were then utilized to calculate the paleopole (VGP) for the El Campito region. The paleopole is located at Lat. = $73.0^{\circ} \mathrm{N}$, Long. $=170.5^{\circ} \mathrm{E}$, with $D p=5.8^{\circ}$ and $D m=3.9^{\circ}$. This paleopole does not fall on the apparent polar wander path (APWP) of North America (Figure 13). However, a small circle with a radius equal to the colatitude calculated from the mean inclination centered on the sampling site does intersect the APWP of North America at the late Cenozoic segment of North America's APWP, suggesting that rocks were remagnetized during the late Cenozoic and have undergone a subsequent $13.5^{\circ} \pm 5.4^{\circ}$ vertical-axis rotation in a clockwise sense (Figure 13). This intersection also suggests that, by the time of remagnetization, the Vizcaino terrane was situated at the southwestern margin of North America and has not experienced paleomagnetically detectable latitudinal displacement since remagnetization. It is not possible to determine the exact age of remagnetization paleomagnetically because this intersection is statistically indistinguishable from the Eocene, Oligocene, and Miocene poles of North America.

\subsection{Possible Mechanisms for Remagnetization}

[37] The remagnetization of the El Campito section must have occurred at low temperatures, because zeolite minerals are present in the Upper Triassic and Jurassic San Hipolito Formation, which lies stratigraphically beneath the El Campito Valle rocks [Kimbrough, 1985; Hickey, 1986]. In addition, one apatite fission track datum from the El Campito rocks yields a Cretaceous age (D. L. Kimbrough, unpublished data, 1996), suggesting that the rocks were not heated as high as $\sim 125^{\circ} \mathrm{C}$. Heating at slightly elevated temperatures could result from either the burial of the El Campito section by several kilometers of younger Valle strata in the northern Vizcaino Peninsula [Smith and Kimbrough, 1996] or the Cenozoic volcanism that occurred in the Vizcaino Peninsula [Aguillón-Robles et al., 2001]. Chemical processes associated with heating at slightly elevated temperatures could lead to growth of new magnetic grains that are big enough to acquire a strong and stable thermochemical remanent magnetization (TCRM) [McClelland, 1996]. Petrographic data from El Campito do show mineralogical alterations along grain boundaries, suggesting that such a chemical process could have occurred. A recent study shows that magnetic particles a few tens of nanometers in size can be produced at $90^{\circ} \mathrm{C}$ for 336 hours in the laboratory [Guyodo et al., 2003], implying that magnetic grains could grow big enough at slightly elevated temperatures to carry a stable remanence.

[38] The bimodal distribution of magnetic grain sizes corroborates the petrographic evidence that alterations of the detritus may have led to a remagnetization. The coercivity component analyses show that samples contain mainly two coercivity components, $\sim 10-15 \mathrm{mT}$ and $\sim 75-80 \mathrm{mT}$ (Figure 8, Tables $2 \mathrm{a}$ and $2 \mathrm{~b}$ ). The $10-15 \mathrm{mT}$ grains correspond to MD magnetite and contribute $\sim 17 \%$ of the magnetization; whereas the $\sim 75-80 \mathrm{mT}$ grains correspond to PSD grains, accounting for the remaining $\sim 83 \%$ of the magnetization. These two components may collectively result in a PSD-dominated magnetic grain size as indicated by the hysteresis data (Figure 7c). Because the El Campito section represents a high-energy submarine fan depositional environment and generally consists of coarse-grained deposits, it is likely that most of the initial depositional fine-grained particles were carried out into the deep ocean leaving behind the coarse-grained detrital grains and MD-dominated magnetite fractions in the submarine fan deposits sampled at El Campito. Thermochemical alterations could have produced magnetite grains predominately SD or PSD in size, along the boundaries of detrital fragments, that acquired a thermochemical remanent magnetization (TCRM). The finest magnetic grains (on the order of a micron or less) often carry stable and strong remanent magnetizations, so the strong 
TCRMs could have swamped the weak DRMs carried by the MD magnetite grains and dominated the remanence. Apparently, the secondary magnetite grains may have inherited a bedding-parallel foliation, thus mimicking a primary magnetic fabric.

[39] The causes of a late Cenozoic remagnetization may be constrained by examining the geodynamic evolution of the western margin of North America. Since the late Mesozoic, the Farallon-Kula plate had been subducting under the western margin of North America [Engebretson et al., 1985]. During the Cenozoic, the Farallon-Kula oceanic plate experienced episodic fragmentation that resulted in changes of the subduction regimes along the western margin of North America [Stock and Lee, 1994]. The continued subduction of the Pacific basin plates and the interaction of oceanic spreading centers with the continental margin in the late Cenozoic eventually gave rise to the present-day tectonic configuration of the western margin of North America. Given the complex interaction of Pacific basin plates and the continental margin during the late Cenozoic, the deeply buried Valle strata could have undergone an exhumation and the subsequent cooling of the Valle rocks led to the remanence acquisition. If remagnetization was caused by burial heating, such remagnetization could have happened as early as in the Eocene time. Besides burial heating, the late Cenozoic volcanism could have also contributed to the remagnetization. Geochemical studies in Mexico showed subduction-generated inland magmatism during the Eocene-Oligocene and that the volcanic front jumped to the west by the early Miocene [Martin-Barajas et al., 2000]. The westward migration of the volcanic front was believed to result in the development of a Miocene volcanic arc along Baja California [Benoit et al., 2002]. On the Vizcaino Peninsula, Miocene volcanic rocks occur extensively across the peninsula including the $\sim 2500 \mathrm{~km}^{2}$ Santa Clara volcanic field in the southwest and several small volcanic fields in the northwestern part of the peninsula. These Miocene volcanic rocks either cross-cut or unconformably overlie the Cretaceous Valle group in the southern Vizcaino peninsula [Benoit et al., 2002]. Although the exposures of the Miocene volcanic rocks in northern peninsula are few, compared to those in the south, shallow intrusive bodies probably occurred in the northern part of the peninsula, given the Miocene tectonic history of this segment of the convergent margin. A gravimetric study of the Bahia de Los Angeles basin, Baja California [DelgadoArgote and Garcia-Abdeslem, 1999] offers such an example, in which high-density bodies were identified and were interpreted to indicate shallow Miocene basaltic magma reservoirs. Therefore the pervasive Miocene volcanism on the peninsula may have substantially affected the paleomagnetic records of the Cretaceous Valle strata, leading to a late Cenozoic remagnetization. A remagnetization associated with the Miocene volcanism would agree with the interpretation that remanence acquisition occurred between two episodes of tilting, one pre-Miocene and the other postMiocene in age.

\section{Conclusions}

[40] The paleomagnetic study of the middle Cretaceous Valle strata, Baja California, Mexico, yielded high-quality paleomagnetic data and an inclination of $19.1^{\circ}$, which is shallower by $18.9^{\circ}$ than the previously reported shallow inclination from nearby Cedros Island. The lack of tight age constraints on remanence acquisition makes the interpretation of the anomalously shallow inclination very difficult. The examination of paleomagnetic, rock magnetic, and petrographic data and regional tectonic analyses imply that the anomalously shallow inclinations could indicate either a posttilting Tertiary remagnetization or a dramatic southernlythen-northernly terrane displacement in the Cretaceous. The overall evidence appears to favor a remagnetization interpretation. A synthesis of the available data suggests that the remagnetization occurred in the late Cenozoic and the Vizcaino terrane has undergone a clockwise rotation by $13.5^{\circ} \pm 5.4^{\circ}$ with no significant latitudinal displacement since the remagnetization. The geological constraints also indicate that the remagnetization must have occurred at low temperatures $\left(<\sim 120^{\circ} \mathrm{C}\right)$. We tentatively interpret that the low-temperature remagnetization is probably a result of a thermochemical remanent magnetization that was acquired at slightly elevated temperatures due to burial and/or volcanism. The remagnetization could have taken place as early as in Eocene time, if caused by burial, or during the Miocene when extensive volcanism occurred in the Vizcaino Peninsula. The present study has revealed a complicated remanence that resists easy interpretation and suggests caution in studies of similar rocks.

[41] Acknowledgments. This study was supported by National Science Foundation grant EAR-9902712 to KPK and DPS. We thank reviewers Jon Hagstrum, Mike Jackson, and associate editor Randy Enkin who helped improve the manuscript substantially. We thank David L. Kimbrough for providing us accommodation in San Diego before and after our field trip to Mexico, and Jordan Vaughn for field assistance. We would also like to thank the Institute for Rock Magnetism (IRM) in Minneapolis for the use of its facilities. The IRM is funded by the Keck Foundation, the National Science Foundation, and the University of Minnesota. Conversations with Gray E. Bebout, David J. Anastasio, Frank J. Pazagglia, Mike Jackson, and Xiaodong Tan helped clarify some of our thoughts. This manuscript also benefits from discussions with David Kimbrough, Thomas E. Moore, Jon Hagstrum, and Wei-Min Huang. Long Li and Robert King helped with the petrographic observations. Qingsong Liu helped measure some hysteresis loops.

\section{References}

Abbott, P. L., D. P. Smith, W. V. Sliter, and L. A. Saul (1995), Paleogeography of three Paleocene limestones in Baja California, Mexico, in Cenozoic Paleogeography of the Western United States-II, Book 75, edited by A. E. Fritsche, pp. 1-8, Pac. Sect. Soc. for Sediment. Geol., Tulsa, Okla.

Ague, J. J., and M. T. Brandon (1992), Tilt and northward offset of Cordilleran batholiths resolved using igneous barometry, Nature, 360, 146149

Aguillón-Robles, A., T. Calmus, M. Benoit, H. Bellon, R. C. Maury, J. Cotton, J. Bourgois, and F. Michaud (2001), Late Miocene adakites and $\mathrm{Nb}$-enriched basalt from Vizcaino Peninsula, Mexico: Indicators of East Pacific Rise subduction below Southern Baja California?, Geology, $29,531-534$.

Anson, G. L., and K. P. Kodama (1987), Compaction-induced shallowing of the post-depositional remanent magnetization in a synthetic sediment, Geophys. J. R. Astron. Soc., 88, 673-692.

Beck, M. E., Jr. (1991), Case for northward transport of Baja and coastal southern California: Paleomagnetic data, analysis and alternatives, Geology, 19, 506-509.

Benoit, M., A. Aguillon-Robles, T. Calmus, R. C. Maury, H. Bellon, J. Cotten, J. Bourgois, and F. Michaud (2002), Geochemical diversity of late Miocene volcanism in southern Baja California, Mexico: Implication of mantle and crustal sources during the opening of an asthenospheric window, J. Geol., 110, 627-648.

Berry, K. D., and P. L. Miller (1984), Mesozoic biostratigraphy, Vizcaino Peninsula and Cedros Island, Baja California Sur, Mexico, in Geology of 
the Baja California Peninsula, Book 39, edited by A. V. Frizzell, pp. $67-$ 87, Pac. Sect. Soc. for Sediment. Geol., Tulsa, Okla.

Böhnel, H., and L. A. Delgado-Argote (2000), Paleomagnetic data from northern Baja California (Mexico): Results from the Cretaceous San Telmo batholith, Spec. Pap. Geol. Soc. Am., 334, 157-165.

Böhnel, H., L. A. Delgado-Argote, and D. L. Kimbrough (2002), Discordant paleomagnetic data for middle-Cretaceous intrusive rocks from northern Baja California: Latitude displacement, tilt, or vertical axis rotation?, Tectonics, 21(5), 1049, doi:10.1029/2001TC001298.

Boles, J. R., and C. A. Landis (1984), Jurassic sedimentary melange and associated facies, Baja California, Mexico, Geol. Soc. Am. Bull., 95, $513-521$.

Busby, C., D. Smith, W. Morris, and B. Fackler-Adams (1998), Evolutionary model for convergent margins facing large ocean basins: Mesozoic Baja California, Mexico, Geology, 26, 227-230.

Butler, R. F., and W. R. Dickinson (1995), Shallow magnetic inclinations in the Cretaceous Valle Group, Baja California: Remagnetization, compaction or translation? Comments, Tectonics, 14, 218-219.

Butler, R. F., G. E. Gehrels, and W. C. McClelland (1989), Discordan paleomagnetic poles from Canadian Coast Plutonic Complex: Regional tilt rather than large-scale displacement?, Geology, 17, 691-694.

Butler, R. F., W. R. Dickinson, and G. E. Gehrels (1991), Paleomagnetism of coastal California and Baja California: Alternatives to large-scale northward transport, Tectonics, 10, 561-576.

Butler, R. F., G. E. Gehrels, and K. P. Kodama (2001), A moderate translation alternative to the Baja British Columbia hypothesis, GSA Today, 11, 4-10.

Coney, P. J., D. L. Jones, and J. W. H. Monger (1980), Cordillera suspect terranes, Nature, 288, 329-333.

Cowan, D. D., M. T. Brandon, and J. I. Garver (1997), Geologic tests of hypotheses for large coastwise displacements-A critique illustrated by the Baja British Columbia controversy, Am. J. Sci., 297, 117-173.

Day, R., M. Fuller, and V. A. Schmidt (1977), Hysteresis properties of titanomagnetites: Grain-size and compositional dependence, Phys. Earth Planet. Inter., 13, 260-267.

Deamer, G. A., and K. P. Kodama (1990), Compaction-induced inclination shallowing in synthetic and clay-rich sediments, J. Geophys. Res., 95, $4511-4529$

Delgado-Argote, L. A., and J. García-Abdeslem (1999), Shallow Miocene basaltic magma reservoirs in the Bahia de Los Angeles basin, Baja California, Mexico, J. Volcanol. Geotherm. Res., 88, 29-46.

Dickinson, W. R., and R. F. Butler (1998), Coastal and Baja California paleomagnetism reconsidered, Geol. Soc. Am. Bull., 110, 1268-1280.

Engebretson, D. C., A. Cox, and R. G. Gordon (1985), Relative motions between oceanic and continental plates in the Pacific Basin, Spec. Pap. Geol. Soc. Am., 206, 59 pp.

Enkin, R. J. (2003), The direction-correction tilt test: An all-purpose tilt/fold test for paleomagnetic studies, Earth Planet. Sci. Lett., 212, 151-166.

Enkin, R. J., and G. S. Watson (1996), Statistical analysis of palaeomagnetic inclination data, Geophys. J. Int., 126, 495-504.

Enkin, R. J., J. B. Mahoney, J. Baker, J. Riesterer, and M. L. Haskin (2003), Deciphering shallow paleomagnetic inclinations: 2. Implications from Late Cretaceous strata overlapping the Insular/Intermontane Superterrane boundary in the southern Canadian Cordillera, J. Geophys. Res., 108(B4), 2185, doi:10.1029/2002JB001983.

Fisher, R. A. (1953), Dispersion on a sphere, Proc. R. Soc. London, Ser. A, 217, 295-305.

Flinn, D. (1953), On tests of significance of preferred orientation in threedimensional fabric diagrams, J. Geol., 55, 526-539.

Fry, J. G., D. J. Bottjer, and S. P. Lund (1985), Magnetostratigraphy of displaced Upper Cretaceous strata in southern California, Geology, 13, $648-651$.

Gastil, G. (1991), Is there a Oaxaca-California megashear? Conflict evidence between paleomagnetic data and other elements of geology, Geology, 19, 502-509.

Gastil, R. G., G. Morgan, and D. Krummenacher (1978), Mesozoic history of peninsular California and related areas east of the Gulf of California, in Mesozoic Paleogeography of the Western United States, Pac. Coast Paleogeogr. Symp., vol. 2, edited by D. G. Howell and K. A. McCougall, pp. 107-116, Soc. of Econ. Paleontol. and Mineral., Sacramento, Calif.

Gehrels, G. E., J. H. Stewart, and K. B. Ketner (2002), Cordilleran-margin quartzites in Baja California-Implications for tectonic transport, Earth Planet. Sci. Lett., 199, 201-210.

Guyodo, Y., A. Mostrom, R. L. Penn, and S. K. Banerjee (2003), From Nanodots to Nanorods: Oriented aggregation and magnetic evolution of nanocrystalline goethite, Geophys. Res. Lett., 30(10), 1512, doi:10.1029/ 2003GL017021.

Hagstrum, J. T. (1992), Remagnetization of the Coast Range ophiolite at Stanley Mountain, California, during accretion near $10^{\circ} \mathrm{N}$ paleolatitude, Geology, 20, 503-506.
Hagstrum, J. T., and P. E. Filmer (1990), Paleomagnetic and tectonic constraints on the Late Cretaceous to early Tertiary northward translation of the Baja California Peninsula, Geofis. Int., 29, 175-184.

Hagstrum, J. T., and B. L. Murchey (1993), Deposition of Franciscan Complex cherts along the paleoequator and accretion to the American margin at tropical paleolatitudes, Geol. Soc. Am. Bull., 105, 766-778.

Hagstrum, J. T., and B. L. Murchey (1996), Paleomagnetism of Jurassic radiolarian chert above the Coast Range ophilite at Stanley Mountain, California, and implications for its paleogeographic origins, Geol. Soc. Am. Bull., 108, 643-652.

Hagstrum, J. T., and R. L. Sedlock (1990), Remagnetization and northward translation of Mesozoic red chert from Cedros Island and the San Benito Islands, Baja California, Mexico, Geol. Soc. Am. Bull., 102, 983-991

Hagstrum, J. T., and R. L. Sedlock (1992), Paleomagnetism of Mesozoic red chert from Cedros Island and the San Benito Islands, Baja California, Mexico revisisted, Geophys. Res. Lett., 19, 329-332.

Hagstrum, J. T., and R. L. Sedlock (1998), Remagnetization of Cretaceous forearc strata on Santa Margarita and Magdalena Islands, Baja California Sur: Implications for northward transport along the California margin, Tectonics, 17, 872-882.

Hagstrum, J. T., M. McWilliams, D. G. Howell, and S. Grommé (1985), Mesozoic paleomagnetism and northward translation of the Baja California Peninsula, Geol. Soc. Am. Bull., 96, 1077-1090.

Hagstrum, J. T., M. G. Sawlan, B. P. Hausback, J. G. Smith, and C. S. Grommé (1987), Miocene paleomagnetism and tectonic setting of the Baja California peninsula, Mexico, J. Geophys. Res., 92, 2627-2639.

Hagstrum, J. T., M. L. Martínez, and D. York (1993), Paleomagnetic and ${ }^{40} \mathrm{Ar} /{ }^{39} \mathrm{Ar}$ evidence for remagnetization of Mesozoic oceanic rocks on the Vizcaino peninsula, Baja California Sur, Mexico, Geophys. Res. Lett., 20, $1831-1834$

Hickey, J. J. (1986), Stratigraphy, sedimentology, and petrology of the JuraCretaceous Eugenia Formation, Punta Eugenia area, Vizcaino Peninsula, Baja California Sur, Mexico (volcanic), Ph.D. thesis, 661 pp., Univ. of Calif., Santa Barbara.

Housen, B. A., and M. E. Beck Jr. (1999), Testing terrane transport: An inclusive approach to the Baja B. C. controversy, Geology, 27, 11431146.

Irving, E., D. J. Thorkelson, P. M. Wheadon, and R. J. Enkin (1995), Paleomagnetism of the Spences Bridge Group and northward displacement of the Intermontane Belt, British Columbia: A second look, J. Geophys. Res., 100, 6057-6071.

Jackson, M. J., S. K. Banerjee, J. A. Marvin, R. Lu, and W. Gruber (1991), Detrital remanence inclination errors and anhysteretic remanence anisotropy: Quantitative model and experimental results, Geophys. J. Int., 104, $95-103$.

Kamerling, M. J., and B. P. Luyendyk (1985), Paleomagnetism and Neogene tectonics of the northern Channel Islands, California, J. Geophys. Res., 90, 12,485-12,502.

Kimbrough, D. L. (1985), Tectonostratigraphic terranes of the Vizcaino Peninsula and Cedros and San Benito Islands, Baja California, Mexico, in Tectonostratigraphic Terranes of the Circum-Pacific Region, Earth Sci. Ser, vol. 1, edited by D. G. Howell, pp. 285-298, Circum-Pac. Counc. for Energy and Min. Resour., Houston, Tex.

Kimbrough, D. L., D. P. Smith, J. B. Mahoney, M. Moore, M. Grove, R. G. Gastil, A. Ortega-Rivera, and C. M. Fanning (2001), Forearc-basin sedimentary response to rapid Late Cretaceous batholith emplacement in the Peninsular Ranges of southern and Baja California, Geology, 29, $491-$ 494.

Kirschvink, J. L. (1980), The least-squares line and plane and the analysis of paleomagnetic data, Geophys. J. R. Astron. Soc., 62, 699-718.

Kodama, K. P. (1997), A successful rock magnetic technique for correcting paleomagnetic inclination shallowing: Case study of the Nacimiento Formation, New Mexico, J. Geophys. Res., 102, 5193-5206.

Kodama, K. P., and J. M. Davi (1995), A compaction correction for the paleomagnetism of the Cretaceous Pigeon Point formation of California, Tectonics, 14, 1153-1164.

Kodama, K. P., and P. D. Ward (2001), Compaction-corrected paleomagnetic paleolatitudes for Late Cretaceous rudists along the Cretaceous California margin: Evidence for less than $1500 \mathrm{~km}$ of post-Late Cretaceous offset for Baja British Columbia, Geol. Soc. Am. Bull., 113, 11711178 .

Kruiver, P. P., and H. F. Passier (2001), Coercivity analysis of magnetic phases in sapropel S1 related to variations in redox conditions, including an investigation of the S ratio, Geochem. Geophys. Geosyst., 2(12), doi:10.1029/2001GC000181.

Kruiver, P. P., M. J. Dekkers, and D. Heslop (2001), Quantification of magnetic coercivity components by the analysis of acquisition curves of isothermal remanent magnetization, Earth Planet. Sci. Lett., 189, $269-276$ 
Lowrie, W. (1990), Identification of ferromagnetic minerals in a rock by coercivity and unblocking temperature properties, Geophys. Res. Lett., 17, 159-162.

Mahoney, J. B., R. J. Enkin, and M. Haskin (2001), Paleomagnetic constraints on terrane translation: The Churn Creek succession in south central British Columbia, Eos Trans. $A G U$, 82(47), Fall Meet. Suppl., Abstract GP11A-0192.

Martin-Barajas, A., J. M. Fletcher, M. Lopez-Martinez, and R. MendozaBorunda (2000), Waning Miocene subduction and arc volcanism in Baja California: The San Luis Gonzaga volcanic field, Tectonophysics, 318 , 27-51.

McBride, E. F. (1963), A classification of common sandstones, J. Sediment Petrol., 33, 664-669.

McCabe, C., M. Jackson, and B. B. Ellwood (1985), Magnetic anisotropy in the Trenton limestone: Results of a new technique, anisotropy of anhysteretic susceptibility, Geophys. Res. Lett., 12, 333-336.

McClelland, E. (1996), Theory of CRM acquired by grain growth, and its implications for TRM discrimination and palaeointensity determination in igneous rocks, Geophys. J. Int., 126, 271-280.

Moore, T. E. (1985), Stratigraphy and tectonic significance of the Mesozoic tectonostratigraphic terranes of the Vizcaino Peninsula, Baja California Sur, Mexico, in Tectonostratigraphic Terranes of the Circum-Pacific Region, Earth Sci. Ser, vol. 1, edited by D. G. Howell, pp. 315-329, Circum-Pac. Counc. for Energy and Min. Resour., Houston, Tex.

Morris, L. K., S. P. Lund, and D. J. Bottjer (1986), Paleolatitude drift history of displaced terranes in southern and Baja California, Nature, $321,344-347$.

Morris, W., D. P. Smith, and C. J. Busby (1989), Conglomerate facies and processes in shallow to deep-marine Cretaceous forearc basins of Baja California, Mexico (abstract), AAPG Bull., 73, 547.

Ortega-Rivera, A., E. Farrar, J. A. Hanes, D. A. Archibald, R. G. Gastil, D. L. Kimbrough, M. Zentilli, M. López-Martínez, G. Féraud, and G. Ruffet (1997), Chronological constraints on the thermal and tilting history of the Sierra San Pedro Martir pluton, Baja California, México, from $\mathrm{U} / \mathrm{Pb},{ }^{40} \mathrm{Ar} /{ }^{39} \mathrm{Ar}$, and fission-track geochronology, Geol. Soc. Am Bull., 109, 728-745.

Özdemir, Ö., D. J. Dunlop, and B. M. Moskowitz (1993), The effect of oxidation on the Verwey transition in magnetite, Geophys. Res. Lett., 20 , $1671-1674$

Patterson, D. L. (1984), Paleomagnetism of the Valle Formation and the Late Cretaceous paleogeography of the Vizcaino basin, Baja California, in Geology of Baja California Peninsula, Mexico, Publ. 39, edited by V. A. Froizzell Jr., pp. 173 -182, Pac. Sect. Econ. Paleontol. and Mineral., Bakersfield, Calif

Rangin, C. (1978), Speculative model of Mesozoic geodynamics, central Baja California to northeastern Sonora (Mexico), in Mesozoic Paleogeography of the Western United States, Pac. Coast Paleogeogr. Symp., vol. 2, edited by D. G. Howell and K. A. McCougall, pp. 85-106, Soc. of Econ. Paleontol. and Mineral., Sacramento, Calif.

Rees, A. I. (1961), The effect of water currents on the magnetic remanence and anisotropy of susceptibility of some sediments, Geophys. J., 5, 235 251.
Rees, A., and W. Woodall (1975), The magnetic fabrics of some laboratory deposited sediments, Earth Planet. Sci. Lett., 25, 121-130.

Sedlock, R. L., F. Ortega-Tugierrez, and R. C. Speed (1993), Tectonostratigraphic terranes and tectonic evolution of Mexico, Spec. Pap. Geol. Soc. Am., 278, 153 pp.

Smith, D. P., and C. J. Busby (1993a), Shallow magnetic inclinations in the Cretaceous Valle Group, Baja California: Remagnetization, compaction or translation?, Tectonics, 12, 1258-1266.

Smith, D. P., and C. J. Busby (1993b), Cretaceous extension and tertiary translation along the SW edge of northern America? Evidence from the Valle Group, in Mesozoic Paleogeography of the Western United States, Pac. Coast Paleogeogr. Symp., vol. 2, edited by D. G. Howell and K. A. McCougall, pp. 127-140, Soc. of Econ. Paleontol. and Mineral., Sacramento, Calif.

Smith, D. P., and D. L. Kimbrough (1996), Eustasy and back-arc collapse recorded in Mid-Cretaceous forearc strata (Valle Group) of the northern Vizcaino peninsula (Baja California Sur, Mexico), Geol. Soc. Am. Abstr. Prog., 28, 250.

Smith, D. P., C. J. Busby, and K. D. Berry (1993), Lithostratigraphy of Cretaceous strata, Cedros Island, Baja California, Mexico: Vargas and Pinos formations defined, Cretaceous Res., 14, 337-364.

Stock, M. J., and J. Lee (1994), Do microplates in suduction zones leave a geological record?, Tectonics, 13, 1472-1487.

Sun, W. W., and K. P. Kodama (1992), Magnetic anisotropy, scanning electron microscopy, and $\mathrm{X}$ ray pole figure goniometry study of inclination shallowing in a compacting clay-rich sediments, J. Geophys. Res., 97, 19,599-19,615.

Tan, X. D., and K. P. Kodama (1998), Compaction-corrected inclinations from southern California Cretaceous marine sedimentary rocks indicate no paleolatitudinal offset for the Peninsular Ranges Terrane, J. Geophys. Res., 103, 27,169-27,192.

Tarling, D. H., and F. Hrouda (1993), The Magnetic Anisotropy of Rocks, 217 pp., Chapman and Hall, New York.

Teissere, R. F., and M. E. Beck (1973), Divergent Cretaceous paleomagnetic pole position for the Southern California batholith, U.S.A., Earth Planet. Sci. Lett., 8, 296-300.

Vaughn, J., K. P. Kodama, and D. P. Smith (2004), Correction of inclination shallowing and its tectonic implications: The Cretaceous Perforada formation, Baja California, Earth Planet. Sci. Lett., in press.

Watson, G. S., and R. J. Enkin (1993), The fold test in paleomagnetism as a parameter estimation problem, Geophys. Res. Lett., 20, 2135-2137.

Zijderveld, J. D. A. (1967), AC demagnetization of rocks: Analysis of results, in Methods and Paleomagnetism, edited by D. W. Collinson, K. M. Creer, and S. K. Runcorn, pp. 245-268, Elsevier Sci., New York.

K. P. Kodama and Y.-X. Li, Department of Earth and Environmental Science, Lehigh University, 31 Williams Drive, Bethlehem, PA 18015, USA. (kpk0@lehigh.edu; yol5@lehigh.edu)

D. P. Smith, Division of Science and Environmental Policy, California State University, Monterey Bay, 100 Campus, Seaside, CA 93955, USA. (douglas_smith@csumb.edu) 